\title{
Simultaneous satellite observations of IO and BrO over Antarctica
}

\author{
A. Schönhardt ${ }^{1}$, M. Begoin ${ }^{1}$, A. Richter ${ }^{1}$, F. Wittrock ${ }^{1}$, L. Kaleschke ${ }^{2}$, J. C. Gómez Martín ${ }^{3}$, and J. P. Burrows ${ }^{1}$ \\ ${ }^{1}$ Institute of Environmental Physics (IUP), University of Bremen, Bremen, Germany \\ ${ }^{2}$ KlimaCampus, Institute of Oceanography, University of Hamburg, Hamburg, Germany \\ ${ }^{3}$ Laboratory for Atmospheric and Climate Science, CSIC, Toledo, Spain
}

Correspondence to: A. Schönhardt (schoenhardt@iup.physik.uni-bremen.de)

Received: 11 October 2011 - Published in Atmos. Chem. Phys. Discuss.: 21 December 2011

Revised: 1 June 2012 - Accepted: 2 July 2012 - Published: 25 July 2012

\begin{abstract}
This article reports on satellite observations of iodine monoxide (IO) and bromine monoxide $(\mathrm{BrO})$. The region of interest is Antarctica in the time between spring and autumn. Both molecules, $\mathrm{IO}$ and $\mathrm{BrO}$, are reactive halogen species and strongly influence tropospheric composition. As a result, a better understanding of their spatial distribution and temporal evolution is necessary to assess accurately their role in tropospheric chemistry. Especially in the case of IO, information on its present magnitude, spatial distribution patterns and source regions is still sparse.

The present study is based on six years of SCIAMACHY (SCanning Imaging Absorption spectroMeter for Atmospheric CartograpHY) data recorded in nadir viewing geometry. Multi-year averages of monthly mean IO columns are presented and compared to the distributions of $\mathrm{BrO}$. Influences of the IO air mass factor and the IO absorption cross section temperature dependence on the absolute vertical columns are discussed. The long-term observations of $\mathrm{IO}$ and $\mathrm{BrO}$ columns yield new insight into the temporal and spatial variation of IO above the Antarctic region. The occurrence of IO on Antarctic sea ice in late spring (November) is discovered and presented. In addition, the comparison between $\mathrm{IO}$ and $\mathrm{BrO}$ distributions show many differences, which argues for different mechanisms and individual nature of the release of the two halogen oxide precursors. The state of the ecosystem, in particular the changing condition of the sea ice in late spring, is used to explain the observations of the IO behaviour over Antarctica and the differences between $\mathrm{IO}$ and $\mathrm{BrO}$ distributions.
\end{abstract}

\section{Introduction}

Reactive halogens such as iodine, bromine and their oxides have received growing attention in the past years owing to their strong impact on tropospheric composition. The attention for halogen oxides is intensified by the recently developed space based remote sensing instrumentation, which is yielding their amounts. In particular, reactive halogens deplete ozone and alter the $\mathrm{HO}_{\mathrm{x}}$ and $\mathrm{NO}_{\mathrm{x}}$ ratios, consequently changing the oxidizing capacity of the troposphere. The halogen oxides iodine monoxide (IO) and bromine monoxide $(\mathrm{BrO})$, generated from the reaction of atomic $\mathrm{I}$ and $\mathrm{Br}$ with ozone, play a central role in these processes (Barrie et al., 1988; Solomon et al., 1994; Carpenter et al., 2003; Platt and von Glasow, 2005; Simpson et al., 2007b).

A prominent example of tropospheric ozone loss by halogen chemistry are ozone depletion events in Polar Spring, closely linked to enhanced bromine levels and now understood to be initiated by the bromine explosion mechanism (Barrie et al., 1988; Platt and Hönninger, 2003). Furthermore, interest is motivated by observations that $\mathrm{BrO}$ acts as an oxidizing agent for gaseous mercury leading to enhanced bio-availability of mercury (Schröder et al., 1998; Steffen et al., 2008), and by clear evidence that IO may nucleate via self-reactions to larger iodine oxide molecules (Burkholder et al., 2004) forming atmospheric particles and eventually growing to cloud condensation nuclei (O'Dowd et al., 2002; McFiggans et al., 2004; O'Dowd and Hoffmann, 2005; Saunders et al., 2010).

Iodine atoms may be released by photolysis of precursor substances such as $\mathrm{I}_{2}$ or volatile iodocarbons emitted from the marine biosphere. Inorganic release processes are also being considered, but they are so far uncertain. Bromine 
precursors include organic as well as inorganic sources. The onset of the rapid bromine explosion was identified to be an inorganic mechanism. Through cross reactions between IO and $\mathrm{BrO}$, the chemistry of the two halogens is linked. In this respect, the ozone destruction potential of IO and $\mathrm{BrO}$ together is larger than the sum of the individual impacts (Vogt et al., 1999). Modeling calculations have also shown that IO has a substantial impact on tropospheric composition even at small amounts (Vogt et al., 1999), and that neglecting tropospheric iodine and bromine chemistry in previous model studies may explain discrepancies between measured and predicted amounts of species like $\mathrm{O}_{3}, \mathrm{OH}$ and $\mathrm{HO}_{2}$ (Bloss et al., 2005; Read et al., 2008).

The occurrence of $\mathrm{IO}$ and $\mathrm{BrO}$ indicates ongoing active halogen chemistry. Knowledge of the abundances, distributions and variations of $\mathrm{IO}$ and $\mathrm{BrO}$, spatially as well as temporally, is therefore necessary. Tropospheric $\mathrm{BrO}$ was first measured by Hausmann et al. (1994) using groundbased long-path DOAS (Differential Optical Absorption Spectroscopy) measurements, and by Wittrock et al. (1996) and Miller et al. (1997) using scattered sunlight DOAS observations. After $\mathrm{BrO}$ was observed in the Antarctic lower stratosphere by ground-based spectroscopy (Solomon et al., 1989; Carroll et al., 1989) and insitu aircraft measurements (Brune et al., 1989), Kreher et al. (1997) provided evidence of boundary layer $\mathrm{BrO}$ in the Antarctic also using passive DOAS measurements. Satellite observations in 1998 first showed the widespread nature of $\mathrm{BrO}$ occurrence in Polar Spring (Richter et al., 1998; Wagner and Platt, 1998).

IO was first detected in the atmosphere in 1999 by Alicke et al. by ground-based, active DOAS in the mid-latitudes, and its occurrence was linked to a combination of close-by algae beds, low tide, and strong solar illumination (Carpenter et al., 1999). Since then, further measurement campaigns have observed IO by active and passive DOAS in the marine boundary layer (MBL) at several locations of the world, e.g. at mid-latitude coasts and (sub)-tropical marine sites (Allan et al., 2000; Peters et al., 2005; Saiz-Lopez et al., 2006; Oetjen, 2009) and in Polar Regions (Wittrock et al., 2000; Frieß et al., 2001; Saiz-Lopez et al., 2007a) with typical concentrations up to a few ppt. IO amounts in the Arctic were found to be much lower than in the Antarctic, and often below detection limit (Hönninger et al., 2004; Mahajan et al., 2010). Two in-situ methods, cavity ring-down spectroscopy as well as the technique of laser induced fluorescence, were successfully used to determine IO concentrations in the midlatitude MBL (Wada et al., 2007; Whalley et al., 2007). Measurements from balloons so far show that IO amounts in the stratosphere are below detection limit of 0.1 ppt (Pundt et al., 1998; Bösch et al., 2003; Butz et al., 2009), however, no such investigations have been performed in Antarctica yet.

Through laboratory studies, better understanding of the reaction pathways of IO and its products has been achieved (Himmelmann et al., 1996; Bloss et al., 2001; Gómez Martín et al., 2007, 2009), and incubation studies have demonstrated the release of iodocarbons from algae and phytoplankton (Pedersén et al., 1996). Interestingly, polar algae seem to emit larger amounts of iodine compounds than their subtropical relatives (Giese et al., 1999), similar to cold water diatoms in comparison to temperate species (Tokarczyk and Moore, 1994; Moore et al., 1996).

Focussing on iodine species in Antarctica, IO has been observed at a few locations by ground-based instruments (Frieß et al., 2001, 2010; Saiz-Lopez et al., 2007a). Large amounts around $10 \mathrm{ppt}$ with singular events up to $20 \mathrm{ppt}$ have been detected occasionally in the boundary layer. However, the abundances are highly variable. Concerning the altitude profile of IO, knowledge is rather limited. Significant abundances in large altitudes have not yet been detected. The suggestion that IO is situated in the boundary layer, possibly only in the lowest few tens of metres, is supported by modeling studies (Saiz-Lopez et al., 2008) as well as by recent multi-axis DOAS measurements at Halley, Antarctica (Howard Roscoe, personal communication). Indications were reported that a significant fraction of IO might possibly even be located within the snow (Frieß et al., 2010). Satellite observations reveal substantial amounts of IO above the Antarctic region. Global maps of IO, observed by the satellite sensor SCIAMACHY (SCanning Imaging Absorption spectroMeter for Atmospheric CartograpHY), have been published previously (Schönhardt et al., 2008) with a focus on seasonal averages. A study of four selected days of satellite observations above the Antarctic was published by Saiz-Lopez et al. (2007b).

In the present study, more details on the spatial and temporal variation of IO distributions are presented, based on six entire years of SCIAMACHY observations. The satellite sensor SCIAMACHY will be introduced, and the measurement method and applied retrieval parameters for the $\mathrm{IO}$ and $\mathrm{BrO}$ retrievals are summarized. A focus of the present study is the time series of Antarctic IO maps, for which first the averaging sequence is explained and then the spatial and temporal variation of IO is described. Simultaneous IO and $\mathrm{BrO}$ observations are compared, and due to the importance of the sea ice cover in this area, observations of the sea ice concentrations are used to analyse specific IO occurrences.

\section{Instrument}

SCIAMACHY is a UV-vis-NIR spectrometer measuring in nadir, limb and occultation modes from onboard the European Environmental Satellite (ENVISAT). ENVISAT is moving in a sun-synchronous, near-polar orbit since March 2002 with a local equator crossing time of 10:00 a.m. The wavelength region covered by SCIAMACHY is divided into eight channels within the ranges of $214-1773 \mathrm{~nm}, 1934$ $2044 \mathrm{~nm}$ and $2259-2386 \mathrm{~nm}$. The instrument records direct, scattered and reflected sun light. Measurements used in the present study are nadir observations from channel 3, 
Table 1. Settings for the DOAS retrieval of IO and BrO in this study. For the trace gases taken into account, the temperatures of the respective cross sections are given in brackets.

\begin{tabular}{lll}
\hline Retrieval settings & $\mathrm{IO}$ & $\mathrm{BrO}$ \\
\hline Fitting window & 416 to $430 \mathrm{~nm}$ & 336 to $347 \mathrm{~nm}$ \\
Polynomial degree & 2 (quadratic) & 3 (cubic) \\
Trace gases & $\mathrm{NO}_{2}(223 \mathrm{~K})$ (Bogumil et al., 2003) & $\mathrm{NO}_{2}(223 \mathrm{~K})$ Bogumil et al. (2003) \\
& $\mathrm{O}_{3}(223 \mathrm{~K})$ (Bogumil et al., 2003) & $\mathrm{O}_{3}(223 \mathrm{~K}, 273 \mathrm{~K})$ Bogumil et al. (2003) \\
& $\mathrm{IO}(298 \mathrm{~K})$ (Gómez Martín et al., 2007) & BrO (228 K) Fleischmann et al. (2004) \\
\hline Other features & Ring effect: SCIATRAN calculation Rozanov et al. (2002); Vountas et al. (1998) \\
& Linear intensity offset correction \\
\hline
\end{tabular}

clusters 14 and $15(404-527 \mathrm{~nm})$ with a spectral resolution of around $0.44 \mathrm{~nm}$ and larger, as well as from channel 2, clusters 9 and $10(310-391 \mathrm{~nm})$ with a spectral resolution of $0.26 \mathrm{~nm}$. Further details on the instrument, measurement modes and mission objectives can be found in Burrows et al. (1995); Bovensmann et al. (1999); Gottwald et al. (2006) and Gottwald and Bovensmann (2011).

\section{IO and $\mathrm{BrO}$ retrieval algorithms}

The column amounts of IO and $\mathrm{BrO}$ are quantified by using the well-established DOAS algorithm (Platt and Perner, 1980; Platt and Stutz, 2008). Table 1 lists the relevant retrieval settings. IO is retrieved in the wavelength interval of $416-430 \mathrm{~nm}$, and the fitting window for BrO lies at 336$347 \mathrm{~nm}$. In both cases a high-pass filter polynomial was applied to the measured optical density $\ln \left(I_{0} / I\right)$ in order to eliminate broad-band spectral structures. Here, $I$ is the analysed nadir spectrum and $I_{0}$ is a reference background spectrum, ideally free of absorber influences. For the case of $\mathrm{BrO}$, a daily solar spectrum was chosen as $I_{0}$. An improved retrieval quality was achieved by the choice of an averaged daily earthshine spectrum in the case of IO (Schönhardt et al., 2008).

The IO retrieval had originally been tested in spectral regions also including wavelengths above $430 \mathrm{~nm}$. By using e.g. the spectral window of $418-438 \mathrm{~nm}$, similar results, especially in pattern, were obtained as compared to results then reported by Saiz-Lopez et al. (2007b). However, using the larger spectral windows, also noticeably large fitting errors in the areas of supposed IO observation had occurred. There is an interference, which we attribute to residual error associated with the atmospheric radiative transfer in strong Fraunhofer lines. This makes the larger spectral windows at present unsuitable for IO retrieval from space. Consequently, the retrieval had been moved to a different fitting window to avoid the Fraunhofer band around $430.5 \mathrm{~nm}$ (Schönhardt et al., 2008).

Another question relevant to the IO retrieval is the dependence of its absorption spectrum on temperature (cf. BrO, Fleischmann et al., 2004). Although previous labora- tory work has found a significant dependence on temperature of the IO peak absorption cross section of the (4-0) band (Bloss et al., 2001), full range spectra at low temperatures have not been reported to date. Moreover, no attempt has been made to quantify the systematic error resulting from using the $298 \mathrm{~K}$ reference spectrum for ground- or satellite-based observations in Polar Regions. In order to elucidate this question, laboratory experiments have been carried out where low resolution IO spectra have been recorded in the temperature range between 233 and $298 \mathrm{~K}$ (see Supplement). These experiments show that as a result of depopulation of high rotational levels of the ground vibrational state with decreasing temperature, the IO bands become narrower and grow higher, resulting in a difference of $35 \%$ between the (4-0) band peak-to-valley cross sections at 233 and $298 \mathrm{~K}$. The overall effect when using the $298 \mathrm{~K}$ reference spectrum for atmospheric retrievals at $243 \mathrm{~K}$ is an overestimation of around $20 \%$ of IO concentrations or column densities. Due to the simultaneous narrowing and growing of the absorption bands at colder temperatures, the magnitude of the temperature effect depends on the spectral resolution of the recording spectrometer. At a finer spectral resolution (such as for SCIAMACHY) a slightly stronger influence is expected, while a broader resolution will attenuate the temperature effect. More information as well as the temperature dependent reference spectra of IO are being made available at http://www.iup.physik.uni-bremen.de/gruppen/ molspec/databases/referencespectra/iospectra/index.html.

From the DOAS retrieval, the slant columns of the trace gases are determined. The slant column is the average of the trace gas density integrated over the specific light paths of the recorded light. In order to transform this amount into a vertical column, i.e. the trace gas concentration integrated vertically through the altitude layers, the air mass factor (AMF) needs to be applied. The AMF describes the relative light path length through an absorber layer and is represented by the ratio of slant column to vertical column.

The averaged IO vertical column above Antarctica for the years 2004 to 2009 is shown as first overview in Fig. 1. Average columns reach up to $1.9 \times 10^{12}$ molec $\mathrm{cm}^{-2}$. For individual measurements, also larger IO amounts are detected. 


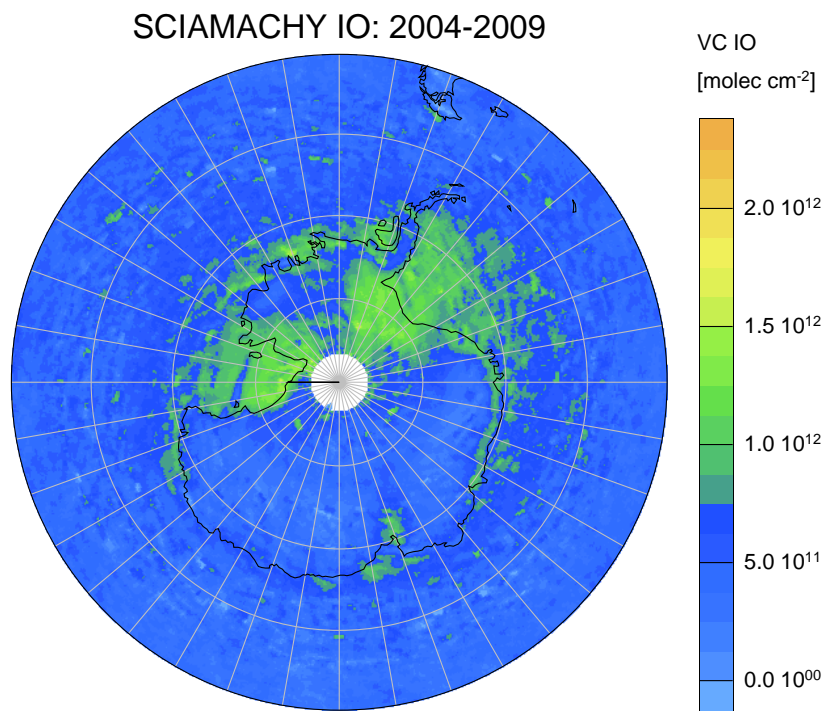

Fig. 1. IO vertical columns above the Antarctic region averaged over the total period of six years, from 2004 to 2009. Different types of areas show enhanced IO amounts - sea ice regions, ice shelves, coast lines, and parts of the continent.

Over widespread areas the vertical column lies between $1.0 \times 10^{12}$ molec cm $^{-2}$ and $1.5 \times 10^{12} \mathrm{molec} \mathrm{cm}^{-2}$.

For the understanding of the IO influence on chemical composition, the amounts in terms of concentrations or mixing ratios are relevant. Starting from column amounts, the computed mixing ratio is strongly dependent on the assumed altitude profile, which is not well known. Assuming the IO to be close to the surface which is in agreement with several previous studies and assumptions (Saiz-Lopez et al., 2008; Frieß et al., 2010), estimations for the boundary layer IO mixing ratios can be derived. In latest studies, however, wide spread and substantial free tropospheric abundances of IO have been reported in tropical regions (Volkamer et al., 2012; Saiz-Lopez et al., 2012). If free tropospheric or even stratospheric abundances of IO are relevant for Antarctic scenes is so far an open issue.

The conversion from vertical columns to mixing ratios and the comparison to long-path DOAS measurements of IO mixing ratios by Saiz-Lopez et al. (2007a) in Antarctica, have been previously discussed in (Schönhardt et al., 2008). A vertical column value of 1.0 or $1.5 \times 10^{12}$ molec cm $\mathrm{cm}^{-2}$ corresponds to a concentration of 1.0 or $1.5 \times 10^{8} \mathrm{molec} \mathrm{cm}^{-3}$ within a $100 \mathrm{~m}$ layer and a mixing ratio of 3.7 or $5.6 \times 10^{-12}$, i.e. 3.7 or $5.6 \mathrm{pptv}$, at $273 \mathrm{~K}$. These values are of the same order of magnitude as observed by Saiz-Lopez et al. (2007a) close to the surface by long-path DOAS observations in the years 2004/05 and by Atkinson et al. (2012) using shipborne multi-axis DOAS in early 2009 when assuming a $200 \mathrm{~m}$ boundary layer. Iodine chemistry with IO amounts on the ppt level may have noticeable influence on atmospheric composition in Polar Regions, especially on $\mathrm{O}_{3}$ levels and
$\mathrm{HO}_{2} / \mathrm{OH}$ and $\mathrm{NO}_{2} / \mathrm{NO}$ ratios (Saiz-Lopez et al., 2007a) as well as particle formation (Atkinson et al., 2012) and potentially also enhanced mercury oxidation via Br (Saiz-Lopez et al., 2008).

Considering a boundary layer box profile, the computed mixing ratio of IO will change approximately by one order of magnitude when assuming a $1 \mathrm{~km}$ instead of a $100 \mathrm{~m}$ thick layer for the case of a bright surface where the AMF hardly depends on the profile shape. The boundary layer in Antarctica can easily be as shallow as $100 \mathrm{~m}$. In any case, the altitude profile will retain its strong influence in the conversion steps, which is even more the case above dark surfaces.

The detection limit for single recordings lies around $7 \times 10^{12} \mathrm{molec}^{-2}$ for the slant column, corresponding to a vertical column around $1.7 \times 10^{12}$ molec cm $\mathrm{cm}^{-2}$ over snow and ice, depending on the AMF. This detection limit is based on the determination of a minimum detectable optical density $\left(\mathrm{OD}_{\min }\right)$ which is obtained directly from the residual of the DOAS fitting result, as discussed in more detail by Schönhardt et al. (2008). The root-mean-quare (RMS) of the residual gives a measure for $\mathrm{OD}_{\min }$. For the conversion to the detection limit in terms of a slant column amount, the absorption cross section of IO is applied. Therefore, the slant column detection limit is temperature dependent. The given numbers represent typical values, which vary between individual measurements. For a typical orbit, e.g., the single measurement RMS in terms of optical density and its standard deviation are $(1.9 \pm 0.5) \times 10^{-4}$ corresponding to an IO slant column detection limit of $(6.8 \pm 1.8) \times 10^{12}$ molec cm $^{-2}$. This detection limit is reduced by temporal averaging, as performed in this study.

The AMFs used here were calculated by the radiative transfer code SCIATRAN (Rozanov et al., 2002, 2005a). A surface spectral reflectance of $a=0.90$ and a pure Rayleigh atmosphere were assumed. Aerosols influence the sensitivity of the measurement and hence the AMF, however, treatment of aerosols has been neglected in the present case as Antarctic aerosol concentrations are fairly low. The aerosol optical thickness (AOT) in Antarctica typically remains well below 0.05 and often below 0.03 as can be seen, e.g., by AERONET measurements (see also http://aeronet.gsfc.nasa.gov/). Low aerosol amounts in Antarctica are also reported by Shaw (1988). Aerosol observations from space over snow and ice are more challenging than over the ocean or land, so a complete set of aerosol information for the time and space covered by the IO analysis is not readily available yet. Using an AOT of 0.05 and assuming all the aerosol to be situated in the boundary layer with the IO, the AMF for IO changes by less than $5 \%$ over most of the SZA range. In an alternative computation using a parameterization of the aerosol load by a visibility of $50 \mathrm{~km}$, an AOT of about 0.08 is represented (Bäumer et al., 2008). Again, the influence on the AMF is $5 \%$ up to $75^{\circ}$ SZA and would rise up to $10 \%$ for very large SZA. Antarctic aerosol abundances typically stay well below these amounts, so the influence on the AMF is usually 


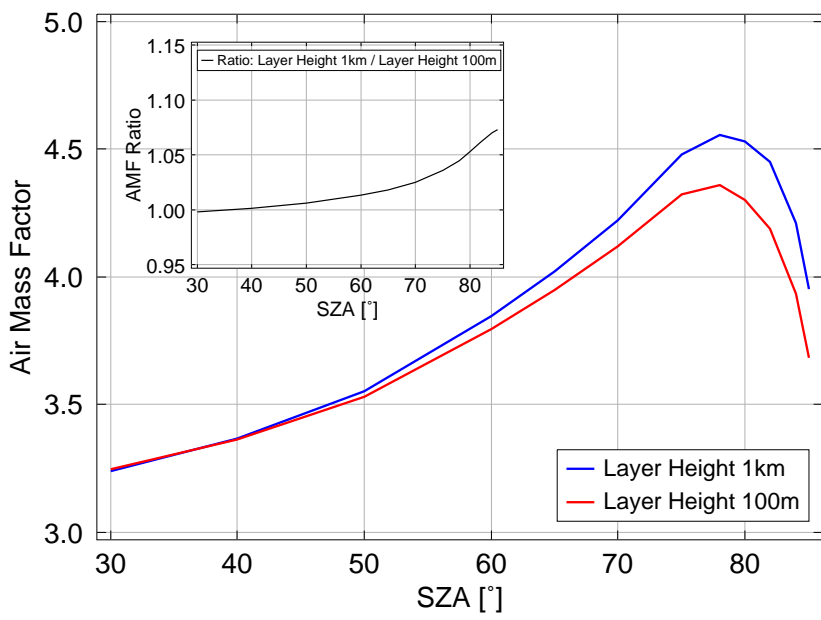

Fig. 2. Calculated AMF for IO using the SCIATRAN radiative transfer code for a Rayleigh atmosphere at $425 \mathrm{~nm}$ above a $90 \%$ reflecting surface. Two different layer heights (LH) are compared, with constant VMR in this layer above the surface, $\mathrm{LH}=1 \mathrm{~km}$ in blue and $\mathrm{LH}=100 \mathrm{~m}$ in red. The inset shows the ratio of the two AMF calculations, i.e. AMF (LH $1 \mathrm{~km}$ ) / AMF (LH $100 \mathrm{~m}$ ). The maximum difference between the two cases lies below $7 \%$.

even smaller. The precise aerosol influence depends on the aerosol characteristics (type, size distribution, altitude profile) as well as on the relative vertical location with respect to the IO, and is therefore variable. The calculations reported above represent rough estimations of the aerosol importance. For the case of bright reflecting surfaces, the influence of aerosols on the AMF remains small in comparison to dark scenes.

Generally, SCIAMACHY offers better sensitivity of IO observations over snow and ice. In the current treatment of Antarctic IO, amounts over the open ocean are underestimated as the surface effect cannot be fully taken into account. A more elaborate consideration of the AMF may be performed as soon as more information on the atmospheric conditions of the considered scenarios is available.

For the AMF calculation, the assumed trace gas profile is an important input information. Current understanding is that most of the IO is situated in the lower boundary layer (Saiz-Lopez et al., 2008; Mahajan et al., 2010). No measurements of significantly large stratospheric iodine amounts above Antarctica have been reported yet. For this study, consequently, a tropospheric IO content at low altitudes is assumed.

The AMF values for IO used in this work, were computed for a wavelength of $425 \mathrm{~nm}$ and varying solar zenith angle (SZA). The result is plotted in Fig. 2. For the final calculation of vertical columns, an IO box profile in the lowest $1 \mathrm{~km}$ of the troposphere was assumed. Clearly, in the near polar regions, boundary layer heights may reduce to much lower altitudes. However, the difference for the AMF when assuming a $1 \mathrm{~km}$ or a $100 \mathrm{~m}$ box profile for IO is fairly small. This can be seen in Fig. 2, where the AMFs for these two profiles in dependence of the SZA are shown, for a $1 \mathrm{~km}$ box profile in blue and for a $100 \mathrm{~m}$ profile in red for comparison. The AMF varies between about 3.1 and 4.6 with changing SZA, and the difference between the two profile cases remains below $7 \%$ above bright surfaces such as snow and ice. The assumed trace gas profile has much larger impact a) above dark surfaces and $b$ ) on deduced values of the volume mixing ratio.

For $\mathrm{BrO}$, the situation is different. Considerable amounts of $\mathrm{BrO}$ are situated in the stratosphere (Rozanov et al., 2005b). In order to take into account the notable amounts of stratospheric $\mathrm{BrO}$ with vertical columns of around $5 \times 10^{13} \mathrm{molec}^{-2}$, a stratospheric AMF is applied to the BrO slant columns (Richter et al., 1998). Depending on the actual vertical distribution, the tropospheric $\mathrm{BrO}$ part tends to be underestimated by this procedure, for smaller SZA some overestimation is possible (up to around $50 \%$ ). The observed spatial patterns of tropospheric $\mathrm{BrO}$ in Antarctica, however, do not depend crucially on the treatment of the AMF. Again, the impact of the profile treatment would be larger over dark scenes. For elaborated studies on $\mathrm{BrO}$ air mass factors, please refer to Begoin et al. (2010) and Theys et al. (2011).

\section{Data set and averaging procedure}

In total, six years of SCIAMACHY nadir data are used in this study. The period covers the years from 2004 to 2009.

Due to the comparably small atmospheric amounts of IO, many of the IO measurements are close to the detection limit of the instrument (Schönhardt et al., 2008), making it necessary to average the IO results over several weeks to months to create maps with sufficient data quality. After applying temporal averaging over suitable periods of time, details on the spatial distribution and temporal variation of IO become visible.

Seasonal patterns of IO repeat in similar form from year to year. Therefore, selected short time periods may be averaged over several subsequent years to improve the signal-tonoise-ratio, and still retain some information on the shorter time scale. As an example, the reoccurrence of IO spatial patterns from year to year is shown in Fig. 3 for the 3-month spring period September to November for all six years 2004 to 2009 individually. In all six years, IO amounts are elevated above the shelf ice regions, around the continent on the sea ice, along coast lines and above parts of the continent. The absolute IO amounts differ from year to year with higher amounts, e.g., in 2006 and lower levels, e.g., in 2009, however, the observed spatial pattern is noticeably similar. The level shift in IO vertical columns between spring 2006 and spring 2009 corresponds to a difference in IO optical depth of below $5 \times 10^{-5}$ (already taking into account the average AMF of 4). The pattern of enhanced IO is more meaningful for this study than the absolute amounts. In further studies, 

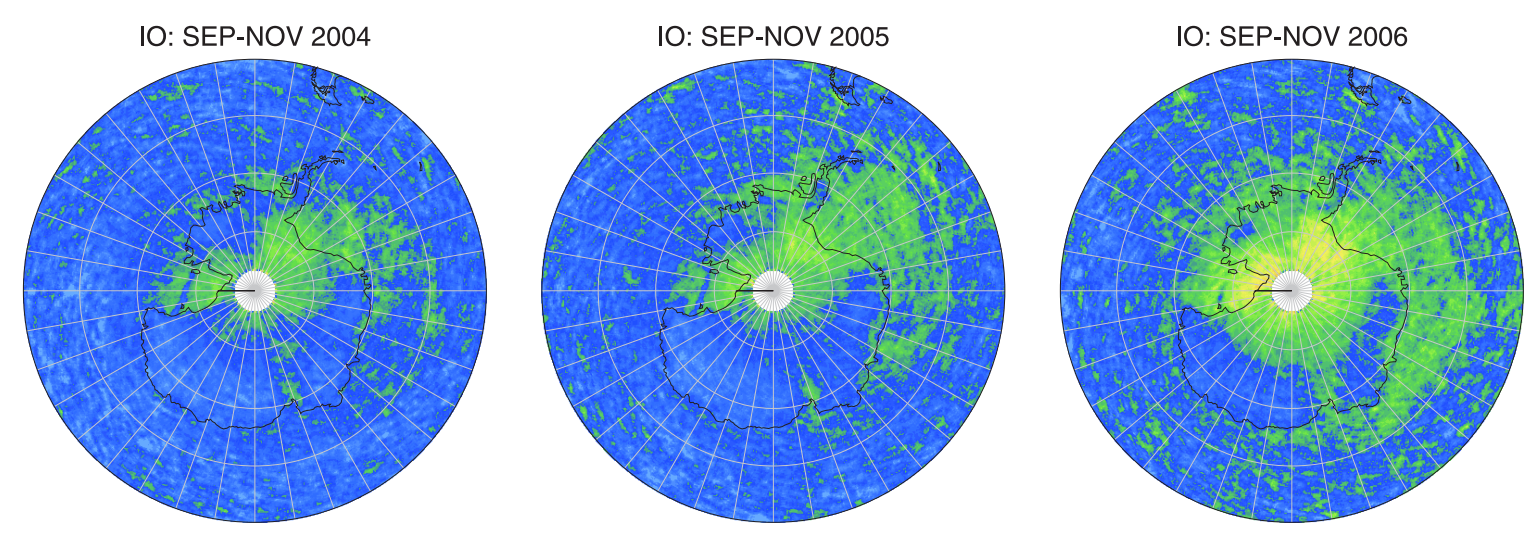

VC IO

[molec $\mathrm{cm}^{-2}$ ]
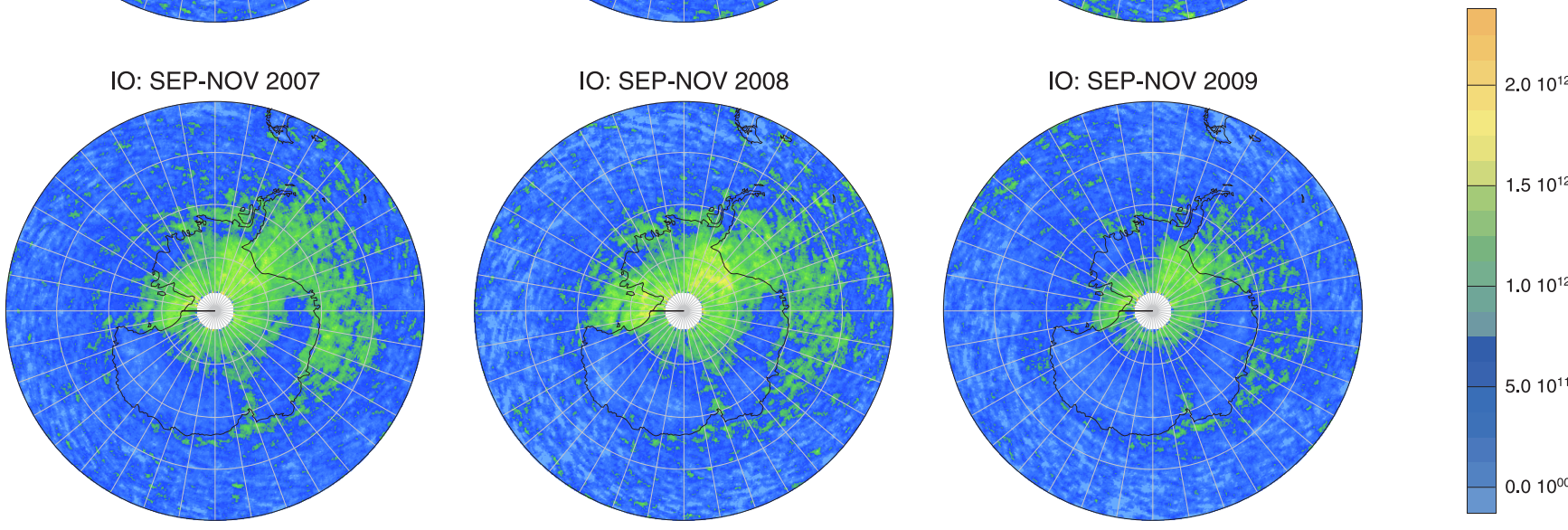

Fig. 3. Spring time averages (September-November) of IO vertical column amounts above the Southern Hemisphere (from $90^{\circ} \mathrm{S}$ to $50^{\circ} \mathrm{S}$ ) for six individual years from 2004 to 2009.

the year to year variation and potential reasons will need to be investigated in more detail.

In the following, monthly means of IO are presented which are averaged over the time span of six years. Averaging periods either start at the beginning or the middle of a month. In this manner, a time series is generated as a running average, where each map is shifted by half a month with respect to the previous image with half a month overlap to both sides. Trace gas variations on effectively shorter time scales may be analysed in this way. The same procedure is applied to the $\mathrm{BrO}$ data for suitable comparison. For both retrievals, the values used for the final results are subject to a quality criterion. Only those results satisfying a limit on the fit residual are considered, excluding individual measurements, e.g., with less than usual signal-to-noise ratio.

\section{Temporal and spatial variation of IO}

The maps in Fig. 4 present a time series of IO vertical columns over Antarctica. The averaging procedure described in Sect. 4 is applied. The first map, e.g., contains data covering the time from 15 September to 14 October from the years 2004 to 2009. The following map then runs from beginning to end of October. For the same periods as for IO, the distributions of $\mathrm{BrO}$ above the Southern Hemisphere are computed and shown in Fig. 5. The BrO maps are discussed and compared to IO distributions later in the following section.

Regions affected by enhanced IO include the sea ice area, shore lines, the ice shelves, and also parts of the continent. Interestingly, above each of these regions enhanced IO appears in different times of the year. In Antarctic early spring time, in the beginning of the time series, IO is enhanced around the shelf ice areas and above parts of the continent. This can be seen in the first map (September/October). Towards later spring, it can be seen how a distinct structure forms. A circular area of enhanced IO amounts around the Antarctic continent begins to evolve in October/November, is fully developed in November and can still be perceived during December. In the circular area, enhanced IO columns lie around $1 \times 10^{12} \mathrm{molec} \mathrm{cm}^{-2}$ to $1.6 \times 10^{12} \mathrm{molec} \mathrm{cm}^{-2}$. The area lies within a part of the ocean still covered by sea ice during this time of year. The sea ice on the ocean is present already during winter and through Antarctic spring time, and slowly starts to break up and melt during spring. The relation between IO appearance and sea ice coverage is discussed below in Sect. 7, where sea ice concentrations are consulted for comparison. 

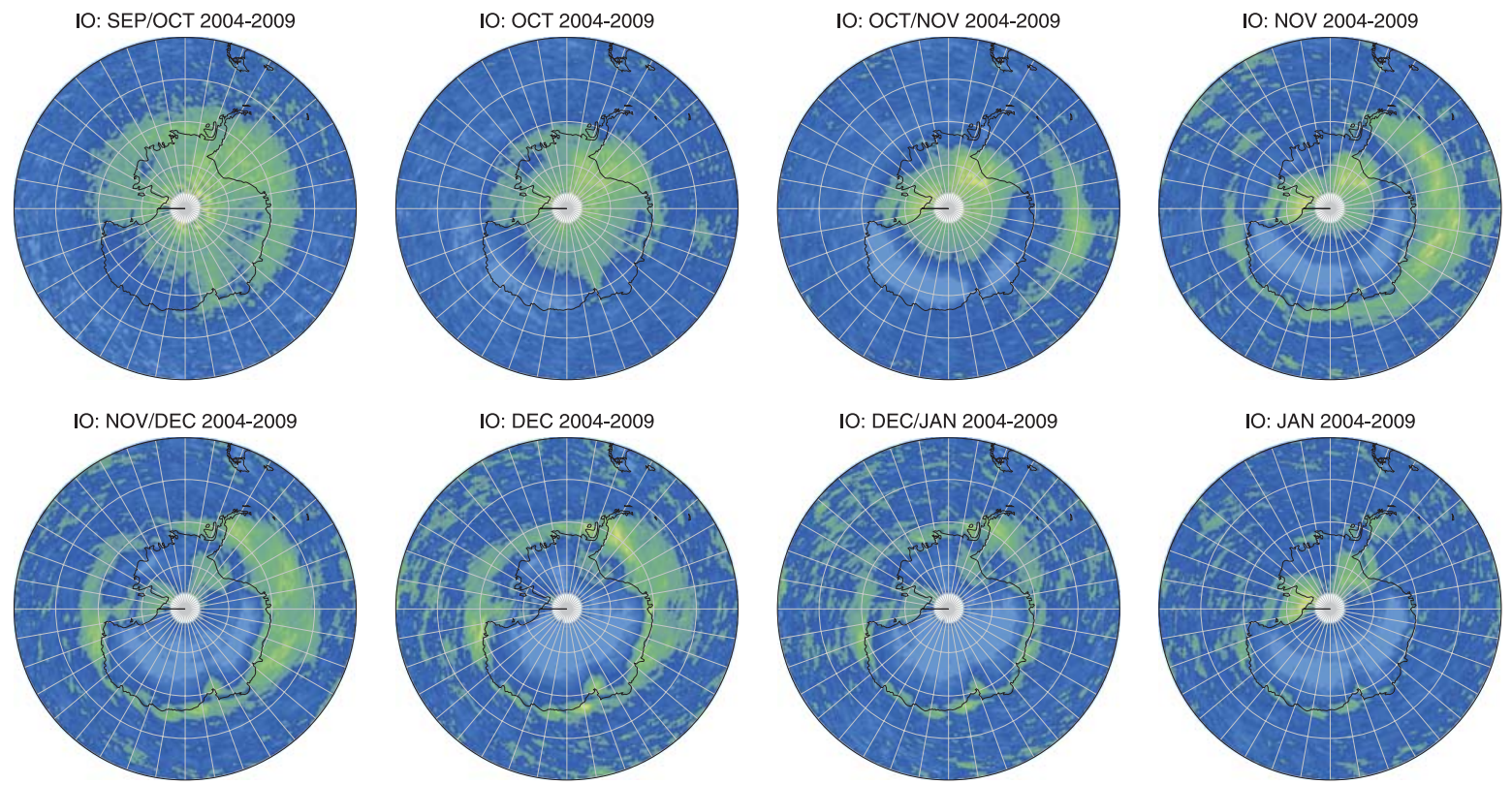

VC IO
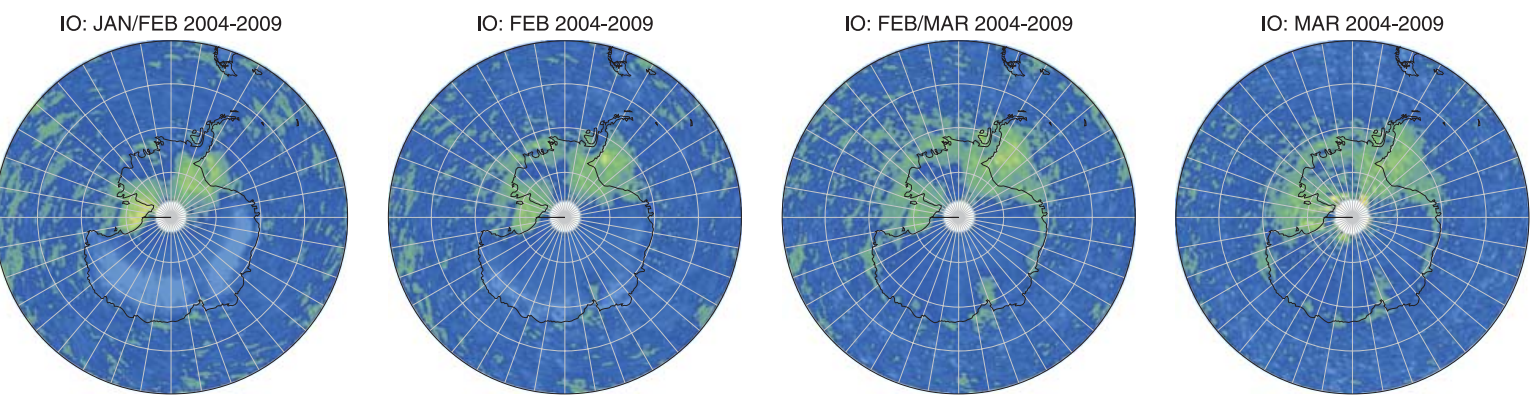

[molec $\left.\mathrm{cm}^{-2}\right]$

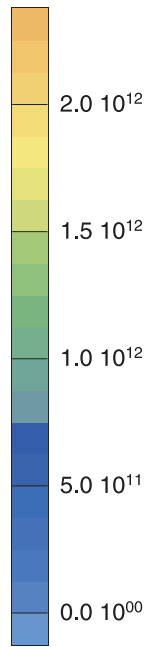

Fig. 4. Monthly maps of IO vertical column amounts on the Southern Hemisphere (up to $50^{\circ} \mathrm{S}$ ) averaged over six subsequent years each (2004-2009), the individual averaging periods are given in the headers.

The area exhibiting enhanced IO then decreases during summer (December and January), enhanced amounts are here mainly found at some coastal locations. In January, the IO is found mostly above some shelf ice areas where it remains present also in early autumn. Towards autumn then the IO becomes more variable, the scattering in the data is enhanced due to less data points and less sun light (larger SZA) and consequently reduced data quality. The enhanced IO amounts are then more widespread in March. In winter, there are no data from scattered sun light measurements.

Following from the discussion on the temperature dependence of the IO absorption, the slight overestimation of IO columns changes with season, with a stronger influence towards the colder months. From typical temperature differences between Antarctic winter and summer of around $\Delta T \approx$ 20-30 K depending on location (Comiso, 2000), a relative difference in retrieved IO amounts of $\leq 10 \%$ results (see also Supplement). A deviation of this magnitude will not significantly influence the observed patterns and temporal-spatial variations of the IO columns, but it should be kept in mind.
By averaging the IO columns over the main latitude band of IO enhancements $\left(\approx 80^{\circ} \mathrm{S}\right.$ to $\left.60^{\circ} \mathrm{S}\right)$, the IO column amounts may be investigated in dependence of the longitude. In this way, the influence of the Solar Zenith Angle (e.g., by photochemistry or measurement sensitivity) is effectively removed. Longitudinal variations of IO enhancements are then caused only by the regional characteristics of the area. The variation of IO amounts with longitude and with time is depicted in Fig. 6. Months from May to July have too little data at the given latitudes, these times appear as white stripes. In the time from August to April each year, the Weddell Sea area and the Ross Sea are regions with frequently large IO columns. Results from a versatile measurement campaign in 2009 confirmed the Weddell Sea area to be rich in iodine chemistry (Atkinson et al., 2012). Other regions, e.g. between $80^{\circ} \mathrm{E}$ and $140^{\circ} \mathrm{E}$ show generally low IO amounts. Regions with less continent but more sea ice area $\left(0^{\circ} \mathrm{E}\right.$ to $\left.-200^{\circ} \mathrm{E}\right)$ show the tendency for larger IO columns. In each year, the shelf ice areas (the Ross Ice Shelf, the Filchner and Ronne Ice Shelves, as well as the smaller Amery Ice Shelf) exhibit enhanced IO columns. In regions 

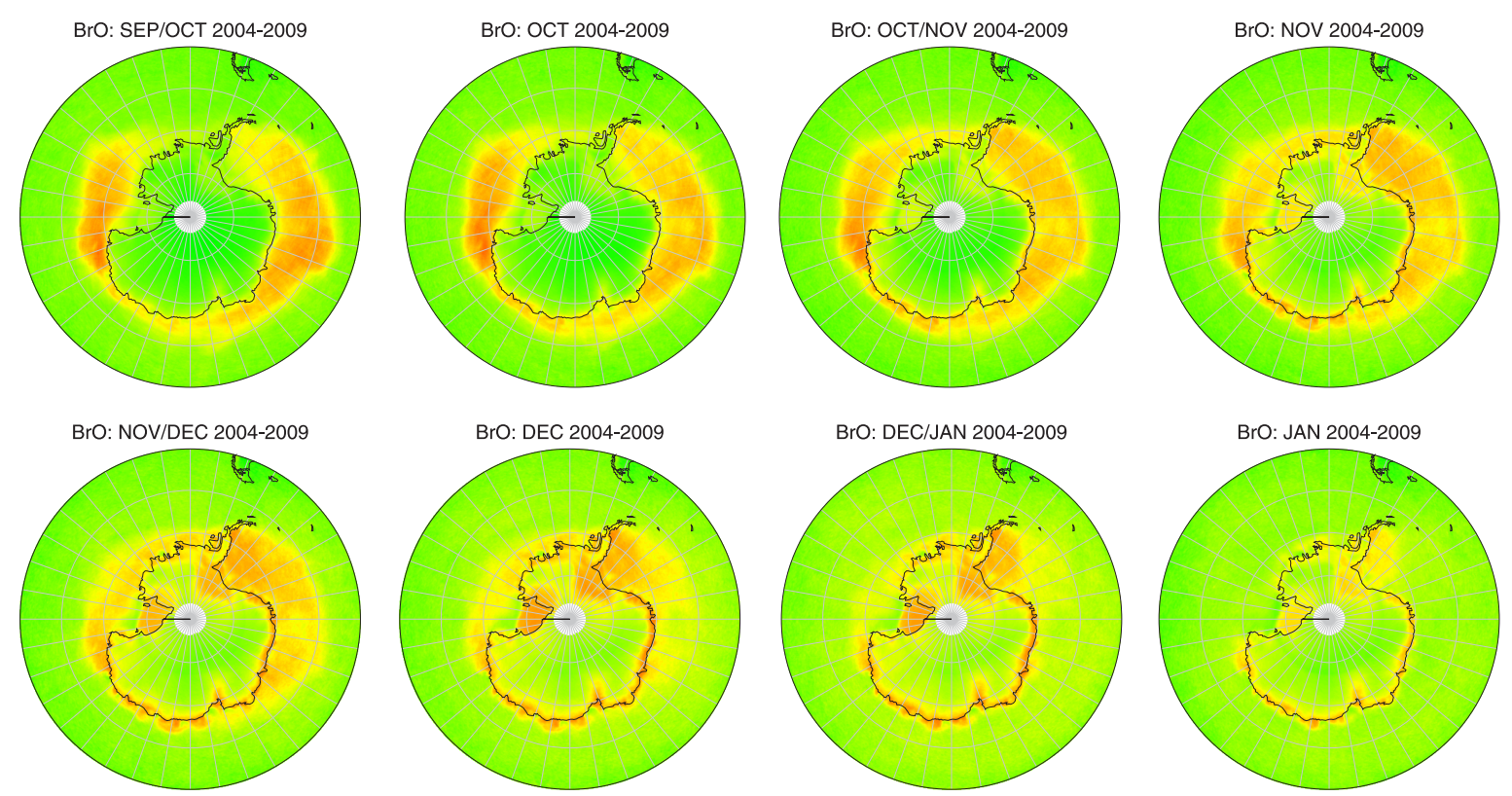

VC BrO

[molec $\mathrm{cm}^{-2}$ ]
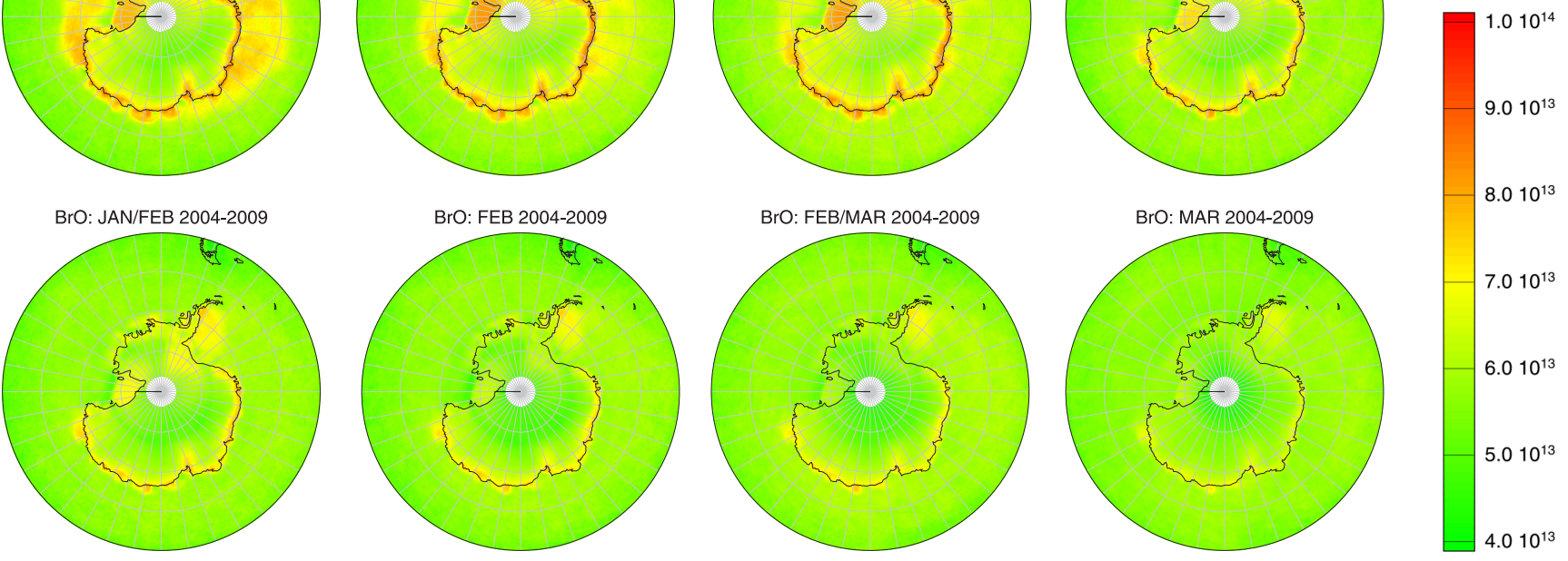

Fig. 5. Monthly maps of $\mathrm{BrO}$ vertical column amounts on the Southern Hemisphere (up to $50^{\circ} \mathrm{S}$ ) averaged over six subsequent years each (2004-2009), the individual averaging periods are given in the headers.

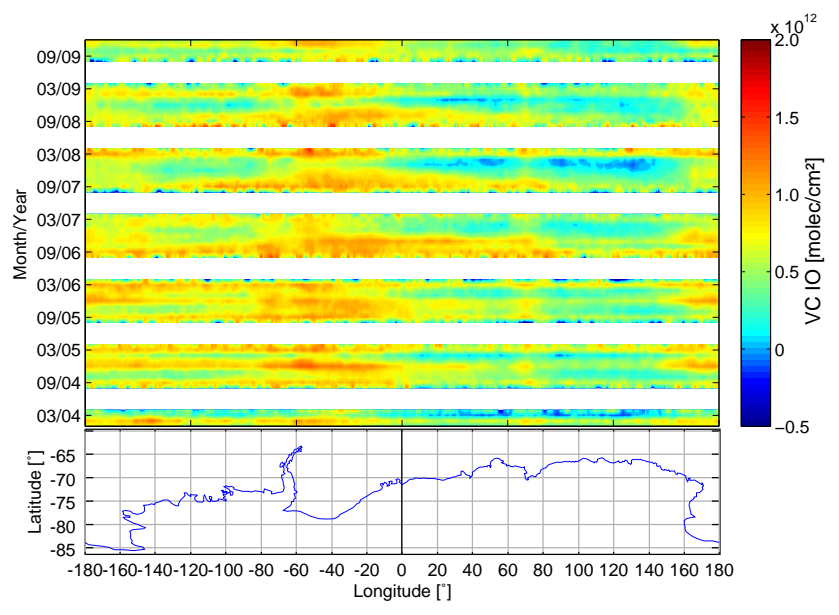

Fig. 6. Contour plot showing the variation of IO average columns with longitude (horizontal axis) and time (vertical axis). IO amounts are averaged within the latitude band $80^{\circ} \mathrm{S}$ to $60^{\circ} \mathrm{S}$. The map below shows the Antarctic coast line. with enhanced IO, the absolute IO values vary with time. It becomes visible again that the overall IO spatial and temporal patterns repeat from year to year. Paying attention to the details, however, some variability in this reoccurrence is recognized. Giving some examples, the absolute IO amounts vary somewhat from year to year, the secondary maximum in autumn (around March) is unequally strong each year, and enhanced IO amounts at certain locations, e.g., at the Amery Ice Shelf at $70^{\circ} \mathrm{E}$, do not appear at exactly the same time each year. The observed detailed differences are subject to variable local environmental conditions.

\section{Comparison of $\mathrm{IO}$ and $\mathrm{BrO}$ distributions}

With respect to reactive halogens and sea ice coverage on the ocean, the circular pattern of enhanced IO in late spring is familiar from observations of $\mathrm{BrO}$. The appearance of widespread $\mathrm{BrO}$ in Polar Spring above sea ice covered regions is well known and has been discussed in preceding publications (Richter et al., 1998; Wagner and Platt, 1998; 
Wagner et al., 2001; Kaleschke et al., 2004; Simpson et al., 2007a).

The distributions of IO, described above, are now compared to those of BrO, shown in Fig. 5 for the same time periods and averaging strategy as for IO. The stratospheric portion of $\mathrm{BrO}$ is effectively masked by the choice of the colour scale, emphasizing the tropospheric contribution. It is known that $\mathrm{BrO}$ appears above Antarctic sea ice (Wagner and Platt, 1998; Richter et al., 2002; Kaleschke et al., 2004), while the necessary conditions are still under discussion and not fully understood. The collected summary of single $\mathrm{BrO}$ appearances in individual areas above the sea ice leads to the characteristic circular pattern around the continent if, e.g., monthly means are considered (Simpson et al., 2007b). Enhanced amounts of $\mathrm{BrO}$ are observed from early spring onwards (i.e. August, not shown here), the circular pattern of $\mathrm{BrO}$ above the sea ice remains fully developed in September/October and persists for several months through the entire spring period, as visible in Fig. 5. BrO columns slowly decrease and retreat during summer. In December, the amounts above the ice shelves are larger than above the sea ice. In addition, the Antarctic coast lines exhibit pronounced $\mathrm{BrO}$, a feature which remains present throughout summer and autumn and decreases gradually.

Comparing the $\mathrm{BrO}$ with the $\mathrm{IO}$ distributions described above, there is one general similarity: $\mathrm{IO}$ and $\mathrm{BrO}$ are both observed in the Antarctic region with highest average amounts in Polar spring time. Some of the affected areas overlap in location and partly in time. Both reactive halogens generally appear on ice shelves, above the sea ice and along coast lines.

Apart from that, mainly differences between the two species and their distributions are identified. One prominent difference is the behaviour above the sea ice area. IO is observed above Antarctic sea ice only for a fairly short period in late spring, while $\mathrm{BrO}$ exhibits its pronounced maximum there during the entire spring period, starting directly after Polar Sunrise and then decreasing from October onwards.

The $\mathrm{IO}$ and $\mathrm{BrO}$ distributions differ in two further aspects partly already mentioned in Schönhardt et al. (2008). Enhanced IO amounts are more widespread above the continent than BrO. Best visible in December in Fig. 5, BrO is present above some parts of the continent extending, e.g., inland from the Ross ice shelf (around $180^{\circ} \mathrm{E}$ ) and the Ronne ice shelf (around $50^{\circ} \mathrm{E}$ ). IO is present in large amounts above parts of the continent in October, mainly inland from the Ronne and Ross ice shelves, and nearly up to the South Pole. While IO amounts increase again towards autumn, e.g., enhanced IO is clearly visible in the Weddell Sea area in March, $\mathrm{BrO}$ amounts gradually decrease over summer and do not reappear in autumn.

\section{Discussion of the observations}

Identification of source regions and release pathways is of major importance in the research of reactive halogens. Satellite observations contribute to the clarification process as they offer a good overview of trace gas abundances in widespread, even remote regions for long time periods. Species with similar source and sink characteristics would show similar distribution patterns. The fact that $\mathrm{IO}$ and $\mathrm{BrO}$ both appear in Antarctic Spring above partly overlapping areas (sea ice, coastal regions) may imply some relation or chemical interaction between the two compounds. Long-path DOAS observations above Halley in 2005 had shown in parts a similar temporal behaviour of the local IO and $\mathrm{BrO}$ amounts (SaizLopez et al., 2007a), from which a close link between the two compounds at this location might be concluded. However, such similarities are not observed for the temporal and spatial distributions of $\mathrm{IO}$ and $\mathrm{BrO}$ on larger scales. The apparent differences in the distributions argue for individual release mechanisms for gaseous iodine and bromine species in Antarctica. An explanation of sudden $\mathrm{BrO}$ release above sea ice by the inorganic bromine explosion mechanism has been established in the past few years (Simpson et al., 2007b; Sander et al., 2006, and references therein). The satellite observations show the different signature of IO and suggest that its release mechanism is of different nature. After a short view on the other regions, the following discussion mainly addresses the sea ice area.

\subsection{Halogen oxides on ice shelves and the continent}

Both species are observed on the shelf ice areas, and as for neither of the two halogens direct sources on the ice shelf are known, the involvement of transport processes in both cases is likely. For $\mathrm{BrO}$, individual transport processes extending over distances up to several thousand kilometres and lasting for several days are regularly observed, e.g., also in the Arctic (Begoin et al., 2010). Chemical recycling processes enable this persistence although the $\mathrm{BrO}$ photolytic life time is much shorter. Enhanced IO extends over the continent even further. This has not been satisfactorily explained yet. Some recycling of IO on the surface and/or aeorosol appears to be likely (Saiz-Lopez et al., 2008). No ground-based measurements are available to clarify the situation. However, transport and recycling of iodine species involving aerosols and snow (Saiz-Lopez et al., 2008) may effectively transfer iodine from marine sources inland, similar to the $\mathrm{BrO}$ transport processes. As a result of IO reactions, iodine oxide compounds are formed which contain iodine acid anhydrides, such as $\mathrm{I}_{2} \mathrm{O}_{3}, \mathrm{I}_{2} \mathrm{O}_{4}$, or $\mathrm{I}_{2} \mathrm{O}_{5}$, the latter being the anhydride of iodic acid $\mathrm{HIO}_{3}$ and strongly hygroscopic (Jimenez et al., 2003). Iodine oxides may act as starting point for new particle formation (Jimenez et al., 2003; Burkholder et al., 2004; Saunders et al., 2010). The initial formation of the acid anhydrides is therefore likely to be an important step in any 
SWFMOCHLO.005 Chlorophyll a concentration climatology [mg/m3] - Jan to Dec

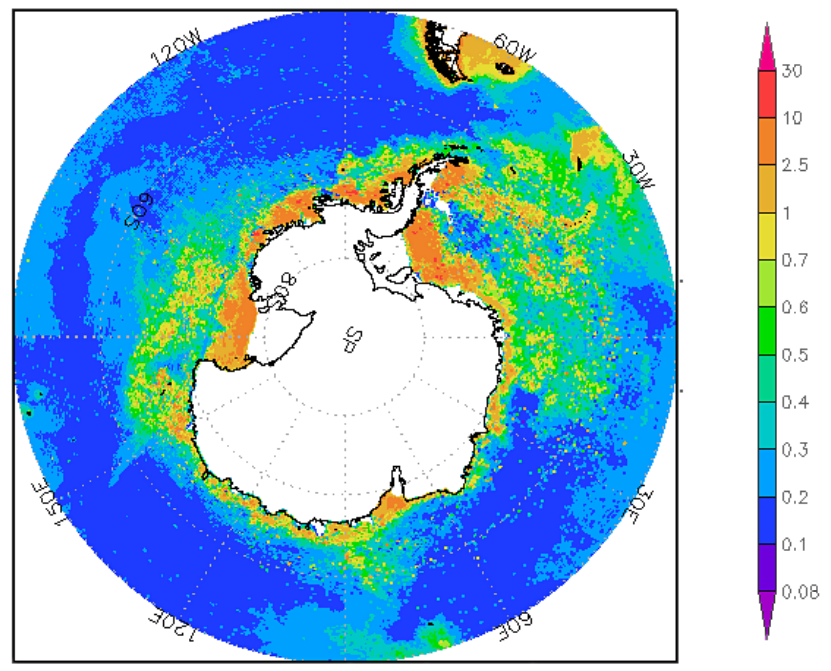

Fig. 7. Map of the chlorophyll $a$ concentration climatology for the Antarctic region. This visualization has been obtained from the Giovanni online data system (Acker and Leptoukh, 2007) developed and maintained by the NASA GES DISC. Observations are based on data from the SeaWiFS and MODIS instruments.

transport and recycling mechanism. In addition, some stratospheric IO occurrence and the influence of strong UV radiation during the ozone hole season might contribute to the observed total IO column. The determination of the details of the mechanism by which iodine is transported into Antarctica producing IO still requires further investigation.

\subsection{Chlorophyll $a$ concentrations around Antarctica}

It has been argued before, that iodine species are probably of biological origin (Alicke et al., 1999). Biogenic iodine release by certain types of macroalgae/phytoplankton has been observed and cold water diatoms produce organic iodine species. Carpenter et al. (2007) have measured organic iodine species in the water columns as well as above the water in the gas phase, and have found substantial amounts of, e.g. $\mathrm{CH}_{2} \mathrm{I}_{2}$, in their case for Antarctic summer. Thus, evidence is provided by point measurements, that iodine species are connected to the surrounding biological activity.

The high biological productivity of Antarctic waters is seen in Fig. 7, showing the chlorophyll $a$ concentration measured by NASA's SeaWIFS (Sea-viewing Wide Field-ofview Sensor) and MODIS (Moderate Resolution Imaging Spectroradiometer) instruments which is an average composite for the years 2004 to 2009. High chlorophyll $a$ concentration indicates strong biological activity. Chlorophyll $a$ concentrations are particularly high close to the Antarctic continent, especially in the waters close to the shelf ice areas, i.e. in the Weddell Sea, the Ross sea and seawards of the Amery ice shelf. In these areas, chlorophyll $a$ is closely correlated to IO occurrence (cf. Fig. 1).
Globally however, the relation between IO and Chl $a$ has not yet been established based on ground-based measurements, because of the sparsity of IO measurements, most of them being taken in coastal locations. Initial investigations based on satellite observations indicate an ambiguous picture, some regions showing a positive relation between $\mathrm{Chl} a$ concentrations and IO amounts and some without such a relation (Schönhardt et al., 2012). Chlorophyll $a$ may not necessarily be a useful proxy for IO appearance.

\subsection{Sea ice cover}

Compared to the $\mathrm{BrO}$ appearance above the Antarctic sea ice, IO abundance evolves comparably late and is temporally restricted mainly to November and December (cf. Figs. 4 and $5)$. This is one of the most interesting differences between the two compounds. After $\mathrm{BrO}$ is generated at polar sunrise, it takes nearly three more months until IO is observed in this area in a similar circular pattern. The appearance of IO above the sea ice is only of short duration of around two months.

With the largest extension of the sea ice cover being present in September (Thomas et al., 2003), the sea ice begins to melt and retreat in the weeks after. During the melting period, not only the total sea ice cover decreases, but more and larger open leads develop, and in addition the still existing sea ice becomes more porous and permeable. Ice algae in Antarctica live and feed from underneath the sea ice (Thomas et al., 2003), and contact with the troposphere above is facilitated in later spring when the ice cover weakens but still offers its habitat to the algae and phytoplankton. In addition to the potential release of iodine from closed sea ice surfaces, for which ideas were developed by Saiz-Lopez and Boxe (2008), the melting and breaking open of sea ice and its increase in temperature and porousness may play an important role.

In order to relate the IO appearance to sea ice cover, observations of sea ice concentrations are used. The sea ice is monitored by the AMSR-E instrument (Advanced Microwave Scanning Radiometer for EOS), a passive microwave radiometer onboard the AQUA satellite which belongs to NASA's Earth Observing System (EOS). Sea ice concentration data used for the maps in Fig. 8 are available from the Integrated Climate Data Center (ICDC, http://icdc.zmaw.de/seaiceconcentration_asi_ amsre.html?\&L=1, KlimaCampus, University of Hamburg). Based on the brightness temperatures measured with the AMSR-E $89 \mathrm{GHz}$ channel, the ice concentration data are a result of the ARTIST Sea Ice (ASI) algorithm (Kaleschke et al., 2001; Spreen et al., 2008). The observed field of view may contain regions with open ocean as well as sea ice covered areas. The sea ice concentration value is defined as the relative area (in percentage) of water covered by sea ice. The left upper map in Fig. 8 shows the average sea ice concentration for October, the right upper map for November, both averaged over the six year period from 2004 to 2009. Regions with 

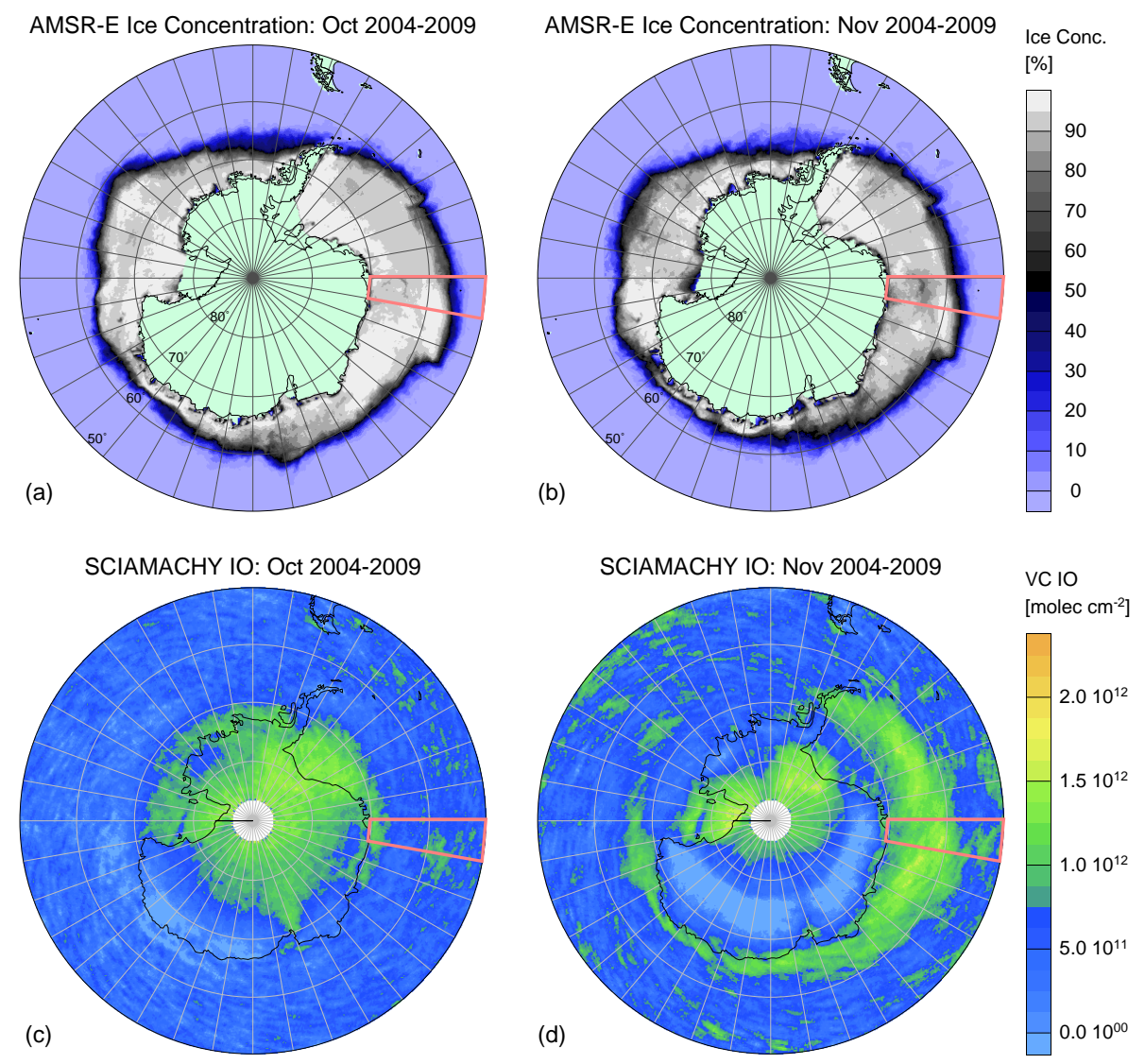

Fig. 8. Maps of the sea ice concentration above Antarctica in October (a) and November (b), averaged over the years 2004 to 2009 each, i.e. the same time period as in Figs. 4 and 5. Data of daily sea ice concentrations are available from the Integrated Climate Data Center (ICDC, http://icdc.zmaw.de, KlimaCampus, University of Hamburg). The boxes mark an example area with internal ice concentration loss between October to November, which is used for analysis in Fig. 9. For comparison, the IO maps for October (c) and November (d) have been repeated here from Fig. 4.

$100 \%$ ice cover are shown in white, and for lesser coverage the brightness decreases through gray to black (around 50\% ice) and then to blue for $0 \%$ ice concentration (i.e. open water). Regions without data are marked in pale turquoise. The sea ice extends circularly around the Antarctic continent, and the ice covered area is smaller for November than for October. In addition, the average concentration of sea ice has already been reduced between the two months which can be seen in the larger dark grey areas within the sea ice zone in the November map. Especially around the coast lines, and at some specific areas within the ice cover, the concentration decreases.

As an example, a closer view on the section between $0^{\circ}$ and $10^{\circ} \mathrm{E}$ shall be taken (box area in Fig. 8). Here, going from October to November, a rise in IO concentrations and a decline in ice concentration is observed (cf. Fig. 8c and d as well as overall time series in Fig. 4 for IO). Figure 9 shows zonally averaged amounts over the stated section of the ice concentrations in October (blue dotted curve) and November (dark blue dashed curve), as well as the difference between

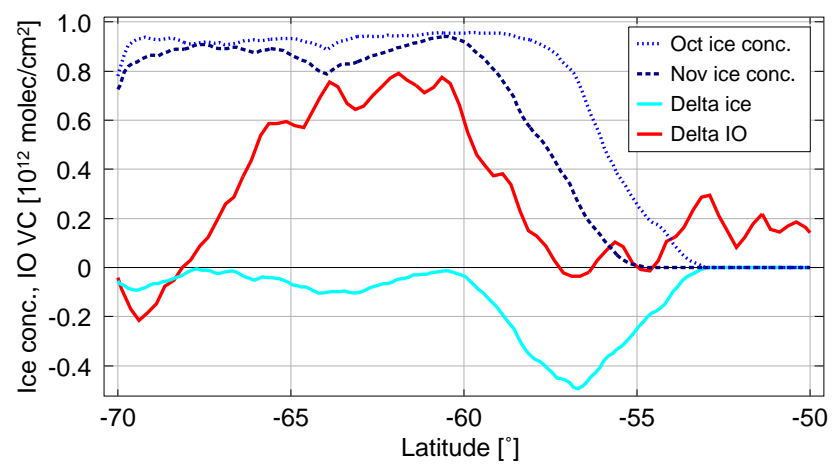

Fig. 9. Comparison of the change in ice cover with the change in IO abundance in the section from $0^{\circ}-10^{\circ} \mathrm{E}$ versus latitude (marked area in Fig. 8). Blue dotted and dark blue dashed lines: the average ice concentration for October and November, respectively. The difference between the two curves is shown in solid light blue (November-October). The solid red curve displays the difference of the IO column amount between November and October. 
the two time periods in solid light blue. From the latter curve, two regions of ice loss are identified, i.e. one between latitudes $-67^{\circ}$ and $-61^{\circ}$ still amid the sea ice circle, and one between latitudes $-60^{\circ}$ and $-53^{\circ}$ at the ice edge. The first dip represents melting and breaking up of the sea ice in still sea ice covered regions, while the second dip represents the retreat of the sea ice cover at the border to the open ocean. The red curve shows the difference in IO vertical column amount between November and October in the same section. The largest enhancement of IO is found between latitudes $-67^{\circ}$ and $-58^{\circ}$, covering the area of sea ice decline amid the sea ice and reaching further northwards.

Assuming that the origin of iodine emissions is from ice algae and phytoplankton, the observed specific IO enhancement is dependent on several factors. In regions with a porous ice cover and many open leads, the contact of the algae species in the water with the air above is facilitated, while the surrounding sea ice still preserves their habitat. As a result, emissions in later spring would be more likely than in early spring emerging from underneath a tightly closed ice cover. Above the comparably warm open ocean areas within the sea ice circle, enhanced convection may enable the insertion of gaseous species to the atmosphere.

The emission of iodine containing compounds into the atmosphere in later spring may also be facilitated by the structure and composition of the ice itself. The probability for liquids to pass through sea ice strongly depends on the temperature of the ice, with a strong increase of permeability at a temperature of around $-5^{\circ} \mathrm{C}$ (Golden et al., 1998). At temperatures above the threshold, water and brine can move through the sea ice. This may have a direct impact on the living species below the sea ice (nutrient transport) as well as on the upward transport of compounds and their insertion into the atmosphere. Closer investigation of the sea ice temperature and its relation to iodine release should be performed by dedicated field work in Antarctica.

For the enhanced IO in earlier spring above regions apart from the sea ice, open ocean directly at the coast may play a role. There is no marked IO enhancement at the ice edge, where the absolute sea ice loss is even larger. This may have at least three explanations: firstly the lower sensitivity of the IO observations above the open ocean as compared to ice and snow, secondly the loss of the algae and phytoplankton preferred habitats when the sea ice vanishes, and thirdly the differences in meteorology such as weaker convection.

Finally, a comparison of the satellite maps of IO and ice concentration and the specific view on the selected section at $0^{\circ}-10^{\circ} \mathrm{E}$ support the observation that IO amounts are amplified above sea ice where the ice cover is breaking open and melting, but where the sea ice habitat is still present.

\section{Summary and conclusions}

Six full years of SCIAMACHY nadir data have been analysed for the trace gas signatures of IO above Antarctica. Monthly periods of vertical column amounts have been computed and averaged over the six years under consideration. The observed IO vertical column is influenced by the considered AMF through the surface reflectance, the aerosol loading and the unknown IO altitude profile. While the AMF variation remains around several percent for scenes with highly reflecting surfaces and low aerosol loadings, stronger variation results over darker surfaces.

The temperature dependence of the IO absorption cross section has been examined to estimate the influence of atmospheric temperatures on observed IO columns. Through application of the $298 \mathrm{~K}$ cross section, an up to $20 \%$ overestimation may result for atmospheric temperatures as low as $243 \mathrm{~K}$ due to deeper and narrower IO excitation lines at colder temperatures. Combined uncertainties due to the IO AMF and fitting inaccuracies are usually larger than the temperature effect.

Strong variations of IO abundances in time and space have been identified above Antarctica. In the detailed temporal resolution, a distinct feature of IO appearance has been discovered. In late spring time, around November and December, a cloud of pronounced IO above the Antarctic sea ice region is regularly observed.

Comparisons of IO and $\mathrm{BrO}$ distributions show that the monthly evolution of these species is different. Although the distributions partly overlap in time and space, considerable differences in the spatial and temporal patterns are observed. Enhanced $\mathrm{BrO}$ is a common feature on Antarctic sea ice during the entire spring period starting from polar sunrise in August and lasting many months, while IO above sea ice appears much later in the year and for a shorter time. The observations support the view that the release pathways of iodine and bromine precursors are probably distinct in origin.

The presented observations and arguments also support the suggestion, that IO release in Antarctica is of biogenic nature. Observations from the SeaWIFS sensor show that areas of high chlorophyll $a$ concentrations and enhanced IO are in close proximity. Observations of sea ice concentrations from the AMSR-E instrument have been considered, and they illustrate that the sea ice concentration decreases in late spring and more open water areas develop still within the sea ice region, enabling closer contact between species in the water column and the troposphere above. Convection above the warmer water as compared to the surrounding ice and air above may facilitate the input of biogenic iodine species to the troposphere.

For a complete understanding of the ongoing biogeochemical cycling of iodine species in the Antarctic sea ice area, detailed in situ studies need to be performed and coupled with improved spatial and temporal resolution remote sensing measurements in the future. In these studies measurements 
in the water column are to be directly combined with flux measurements and trace gas observations in the atmosphere above.

In addition, for an improved understanding of the importance of atmospheric iodine, combined field, satellite and modelling studies would be helpful. Under reasonable assumptions, e.g. on the IO vertical distribution, the presented satellite IO observations would be consistent with a few ppt $\mathrm{IO}$ in the polar boundary layer and therefore a widespread and non negligible impact of iodine chemistry on atmospheric composition. These IO levels would indicate a noticeable influence on Antarctic ozone as well as $\mathrm{OH}$ amounts and particle formation. However, due to the various assumptions that have to be made in the retrieval and can currently not be verified, the satellite data do not yet provide strong constraints on the range of possible surface IO mixing ratios. Dedicated studies investigating this further would include ground-based and aircraft measurements of the temporal and spatial variation and especially of the vertical distribution of iodine species at several representative locations. Model computations based on the input from these reference points may then be extended to further areas by also using satellite IO observations in an upscaling procedure to a regional-to-continental scale, and in this way aim at an improved determination of iodine impact on the atmosphere.

The satellite observations of IO over several years, presented in this manuscript, provide valuable insight into the distribution of IO and its spatial and temporal variation.

\section{Supplementary material related to this article is available online at: http://www.atmos-chem-phys.net/12/ 6565/2012/acp-12-6565-2012-supplement.pdf.}

Acknowledgements. This study has been financially supported by ESA through the TIBAGS project within the CESN framework. Further financial support was received from the State and University of Bremen, the German Aerospace (DLR), and the European Union.

ESA and DLR provided the level 1 data from SCIAMACHY. Sea ice concentration data from AMSR-E observations are available from http://icdc.zmaw.de/seaiceconcentration_asi_amsre.html? $\& \mathrm{~L}=1$. The visualization of chlorophyll $a$ used in this paper was produced with the Giovanni online data system, developed and maintained by the NASA GES DISC.

Edited by: C. McNeil

\section{References}

Acker, J. G. and Leptoukh, G.: Online analysis enhances use of NASA earth science data, Eos, Transactions, American Geophysical Union, 88, 14-17, 2007.

Alicke, B., Hebestreit, K., Stutz, J., and Platt, U.: Iodine oxide in the marine boundary layer, Nature, 572, 397-398, 1999.

Allan, B. J., McFiggans, G., Plane, J. M. C., and Coe, H.: Observations of iodine monoxide in the remote marine boundary layer, J. Geophys. Res., 105, 14363-14369, 2000.

Atkinson, H. M., Huang, R.-J., Chance, R., Roscoe, H. K., Hughes, C., Davison, B., Schönhardt, A., Mahajan, A. S., Saiz-Lopez, A., Hoffmann, T., and Liss, P. S.: Iodine emissions from the sea ice of the Weddell Sea, Atmos. Chem. Phys. Discuss., 12, 1159511639, doi:10.5194/acpd-12-11595-2012, 2012.

Barrie, L. A., Bottenheim, J. W., Schnell, R. C., Crutzen P. J., and Rasmussen, R. A.: Ozone destruction and photochemical reactions at polar sunrise in the lower Arctic atmosphere, Nature, 334, 138-141, 1988.

Bäumer, D. , Vogel, B., Versick, S., Rinke, R., Möhler, O., and Schnaiter, M.: Relationship of visibility, aerosol optical thickness and aerosol size distribution in an ageing air mass over SouthWest Germany, Atmos. Env., 42, 989-998, 2008.

Begoin, M., Richter, A., Weber, M., Kaleschke, L., Tian-Kunze, X., Stohl, A., Theys, N., and Burrows, J. P.: Satellite observations of long range transport of a large $\mathrm{BrO}$ plume in the Arctic, Atmos. Chem. Phys., 10, 6515-6526, http://dx.doi.org/10.5194/ acp-10-6515-2010doi:10.5194/acp-10-6515-2010, 2010.

Bloss, W. J., Rowley, D. M., Cox, R. A., and Jones, R. L.: Kinetics and products of the IO self-reaction, J. Phys. Chem. A, 105, 7840-7854, 2001.

Bloss, W. J., Lee, J. D., Johnson, G. P., Sommariva, R., Heard, D. E., Saiz-Lopez, A., McFiggans, G., Coe, H., Flynn, M., Williams, P., Rickard, A. R., and Fleming, Z. L.: Impact of halogen monoxide chemistry upon boundary layer $\mathrm{OH}$ and $\mathrm{HO}_{2}$ concentrations at a coastal site, Geophys. Res. Lett., 32, L06814, http://dx.doi.org/ 10.1029/2004GL022084doi:10.1029/2004GL022084, 2005.

Bösch, H., Camy-Peyret, C., Chipperfield, M. P., Fitzenberger, R., Harder, H., Platt, U., and Pfeilsticker, K.: Upper limits of stratospheric IO and OIO inferred from center-to-limbdarkening-corrected balloon-borne solar occultation visible spectra: implications for total gaseous iodine and stratospheric ozone, J. Geophys. Res., 108, 4455, http://dx.doi.org/10.1029/ 2002JD003078doi:10.1029/2002JD003078, 2003.

Bogumil, K., Orphal, J., Homann, T., Voigt, S., Spietz, P., Fleischmann, O. C., Vogel, A., Hartmann, M., Bovensmann, H., Frerik, J., and Burrows, J. P.: Measurements of molecular absorption spectra with the SCIAMACHY Pre-Flight Model: instrument characterization and reference data for atmospheric remotesensing in the 230-2380 nm Region, J. Photoch. Photobio. A., 157, 167-184, 2003.

Bovensmann, H., Burrows, J. P., Buchwitz, M., Frerick, J., Noël, S., Rozanov, V. V., Chance, K. V., and Goede, A. P. H.: SCIAMACHY: mission objectives and measurement modes, J. Atmos. Sci., 56, 127-150, 1999.

Brune, W. H., Anderson, J. G., and Chan, K. R.: In situ observations of $\mathrm{BrO}$ over Antarctica: ER-2 aircraft results from $54^{\circ} \mathrm{S}$ to $72^{\circ} \mathrm{S}$ latitude, J. Geophys. Res., 94, 6639-16647, 1989.

Burkholder, J. B., Curtius, J., Ravishankara, A. R., and Lovejoy, E. R.: Laboratory studies of the homogeneous nucleation of 
iodine oxides, Atmos. Chem. Phys., 4, 19-34, http://dx.doi.org/ 10.5194/acp-4-19-2004doi:10.5194/acp-4-19-2004, 2004.

Burrows, J. P., Hölzle, E., Goede, A. P. H., Visser, H., and Fricke, W.: SCIAMACHY - Scanning Imaging Absorption Spectrometer for Atmospheric Chartography, Acta Astronaut., 35, 445-451, 1995.

Butz, A., Bösch, H., Camy-Peyret, C., Chipperfield, M. P., Dorf, M., Kreycy, S., Kritten, L., Prados-Román, C., Schwärzle, J., and Pfeilsticker, K.: Constraints on inorganic gaseous iodine in the tropical upper troposphere and stratosphere inferred from balloon-borne solar occultation observations, Atmos. Chem. Phys., 9, 7229-7242, http://dx.doi.org/10.5194/ acp-9-7229-2009doi:10.5194/acp-9-7229-2009, 2009.

Carpenter, L. J.: Iodine in the marine boundary layer, Chem. Rev., 103, 4953-4962, 2003.

Carpenter, L. J., Sturges, W. T., Penkett, S. A., Liss, P. S., Alicke, B., Hebestreit, K., and Platt, U.: Short-lived alkyl iodides and bromides at Mace Head, Ireland: links to biogenic sources and halogen oxide production, J. Geophys. Res., 104, 1679-1689, 1999.

Carpenter, L. J., Wevill, D. J., Palmer, C. J., and Michels, J.: Depth profiles of volatile iodine and bromine-containing halocarbons in coastal Antarctic waters, Mar. Chem., 103, 227-236, 2007.

Carroll, M. A., Sanders, R. W., Solomon, S., and Schmeltekopf, A. L.: Visible and near-ultraviolet spectroscopy at McMurdo Station, Antarctica. 6. observations of $\mathrm{BrO}$, J. Geophys. Res., 94, D14, 16633-16638, 1989.

Comiso, J. C.: Variability and trends in Antarctic surface temperatures from in situ and satellite infrared measurements, J. Climate, 13, 1674-1696, 2000.

Fleischmann, O. C., Hartmann, M., Burrows, J. P., and Orphal, J.: New ultraviolet absorption cross-sections of $\mathrm{BrO}$ at atmospheric temperatures measured by a time-windowing Fourier transform spectroscopy, J. Photoch. Photobio. A., 168, 117-132, 2004.

Frieß, U., Wagner, T., Pundt, I., Pfeilsticker, K., and Platt, U.: Spectroscopic measurements of tropospheric iodine oxide at Neumeyer station, Antarctica, Geophys. Res. Lett., 28, 1941, http://dx.doi.org/10.1029/ 2003JD004133doi:10.1029/2003JD004133, 2001.

Frieß, U., Deutschmann, T., Gilfedder, B. S., Weller, R., and Platt, U.: Iodine monoxide in the Antarctic snowpack, Atmos. Chem. Phys., 10, 2439-2456, http://dx.doi.org/10.5194/ acp-10-2439-2010doi:10.5194/acp-10-2439-2010, 2010.

Giese, B., Laturnus, F., Adams, F. C., and Wiencke, C.: Release of volatile iodinated $\mathrm{C} 1-\mathrm{C} 4$ hydrocarbons by marine macroalgae from various climate zones, Environ. Sci. Technol., 33, 24322439, 1999.

Golden, K. M., Ackley, S. F., and Lytle, V. I.: The percolation phase transition in sea ice, Science, 282, 2238-2241, http://dx.doi.org/10.1126/science.282.5397. 2238doi:10.1126/science.282.5397.2238, 1998.

Gómez Martín, J. C.: Spectroscopic, Kinetic and Mechanistic Studies of Atmospherically Relevant $\mathrm{I}_{2} / \mathrm{O}_{3}$ Photochemistry, Ph.D. Thesis, University Bremen, Germany, 2006.

Gómez Martín, J. C., Spietz, P., and Burrows, J. P.: Kinetic and mechanistic studies of the $\mathrm{I}_{2} / \mathrm{O}_{3}$ photochemistry, J. Phys. Chem A., 111, 306, http://dx.doi.org/10.1021/ jp061186cdoi:10.1021/jp061186c, 2007.

Gómez Martín, J. C., Ashworth, S. H., Mahajan, A. S., and Plane, J. C. M.: Photochemistry of OIO: lab- oratory study and atmospheric implications, Geophys. Res. Lett., 36, L09802, http://dx.doi.org/10.1029/ 2009GL037642doi:10.1029/2009GL037642, 2009.

Gottwald, M. and Bovensmann, H. (Eds.): SCIAMACHY - Exploring the Changing Earth's Atmosphere, ISBN 978-90-481-9895-5, http://dx.doi.org/10.1007/ 978-90-481-9896-2doi:10.1007/978-90-481-9896-2, Springer, Dordrecht Heidelberg London New York, 2011.

Gottwald, M., Bovensmann, H., Lichtenberg, G., Noel, S., von Bargen, A., Slijkhuis, S., Piters, A., Hoogeveen, R., von Savigny, C., Buchwitz, M., Kokhanovsky, A., Richter, A., Rozanov, A., Holzer-Popp, T., Bramstedt, K., Lambert, J.-C., Skupin, J., Wittrock, F., Schrijver, H., and Burrows, J. P. (Eds.): SCIAMACHY - Monitoring the Changing Earth's atmosphere, DLR, Institut für Methodik der Fernerkundung (IMF), available online at: http://atmos.caf.dlr.de/projects/scops/sciamachy_book/ sciamachy_book_dlr.html, last access: 20 July 2012, 2006.

Hausmann, M. and Platt, U.: Spectroscopic measurement of bromine oxide and ozone in the high Arctic during Polar Sunrise Experiment 1992, J. Geophys. Res., 99, 25399-25413, 1994.

Himmelmann, S., Orphal, J., Bovensmann, H., Richter, A., Ladstätter-Weißenmayer, A., and Burrows, J. P.: First observation of the OIO molecule by time resolved flash photolysis absorption spectroscopy, Chem. Phys. Lett., 251, 330-334, 1996.

Hönninger, G., Leser, H., Sebastián, O., and Platt, U.: Groundbased measurements of halogen oxides at the Hudson Bay by active longpath DOAS and passive MAX-DOAS, Geophys. Res. Lett., 31, L04111, http://dx.doi.org/10.1029/ 2003GL018982doi:10.1029/2003GL018982, 2004.

Jimenez, J. L., Bahreini, R., Cocker III, D. R., Zhuang, H., Varutbangkul, V., Flagan, R. C., and Seinfeld, J. H., O'Dowd, C. D., and Hoffmann, T.: New particle formation from photooxidation of diiodomethane $\left(\mathrm{CH}_{2} \mathrm{I}_{2}\right)$, J. Geophys. Res., 108, 4318, doi:10.1029/2002JD002452, 2003.

Kaleschke, L., Lüpkes, C., Vihma, T., Haarpaintner, J., Bochert, A., Hartmann, J., and Heygster, G.: SSM/I sea ice remote sensing for mesoscale ocean-atmosphere interaction analysis, Can. J. Remote Sens., 27, 526-537, 2001.

Kaleschke, L., Richter, A., Burrows, J. P., Afe, O., Heygster, G., Notholt, J., Rankin, A. M., Roscoe, H. K., Hollwedel, J., Wagner, T., and Jacobi, H.-W.: Frost flowers on sea ice as a source of sea salt and their influence on tropospheric halogen chemistry, Geophys. Res. Lett., 31, L16114, http://dx.doi.org/10.1029/ 2004GL020655doi:10.1029/2004GL020655, 2004.

Kreher, K., Johnston, P. V., Wood, S. W., Nardi, B., and Platt, U.: Ground-based measurements of tropospheric and stratospheric $\mathrm{BrO}$ at Arrival Heights, Antarctica, Geophys. Res. Lett., 24, 3021-3024, 1997.

Mahajan, A. S., Shaw, M., Oetjen, H., Hornsby, K. E., Carpenter, L. J., Kaleschke, L., Tian-Kunze, X., Lee, J. D., Moller, S. J., Edwards, P., Commane, R., Ingham, T., Heard, D. E., and Plane, J. M. C.: Evidence of reactive iodine chemistry in the Arctic boundary layer, J. Geophys. Res., 115, D20303, http://dx.doi. org/10.1029/2009JD013665doi:10.1029/2009JD013665, 2010.

McFiggans, G., Coe, H., Burgess, R., Allan, J., Cubison, M., Alfarra, M. R., Saunders, R., Saiz-Lopez, A., Plane, J. M. C., Wevill, D., Carpenter, L., Rickard, A. R., and Monks, P. S.: Direct evidence for coastal iodine particles from Laminaria macroalgae - linkage to emissions of molecular iodine, 
Atmos. Chem. Phys., 4, 701-713, http://dx.doi.org/10.5194/ acp-4-701-2004doi:10.5194/acp-4-701-2004, 2004.

Miller, H. L., Weaver, A., Sanders, R. W., Arpag, K., and Solomon, S.: Measurements of Arctic sunrise surface ozone depletion events at Kangerlussuaq, Greenland $\left(67^{\circ} \mathrm{N}, 51^{\circ} \mathrm{W}\right)$, Tellus B, 49, 496-509, 1997.

Moore, R. M., Webb, M., Tokarczyk, R., and Wever, R.: Bromoperoxidase and iodoperoxidase enzymes and production of halogenated methanes in marine diatom cultures, J. Geophys. Res., 101, 20899-20908, 1996.

Oetjen, H.: Measurements of halogen oxides by scattered sunlight differential optical absorption spectroscopy, Ph.D. Thesis, University Bremen, Germany, 2009.

O'Dowd, C. D. and Hoffmann, T.: Coastal new particle formation: a review of the current state-of-the-art, Environ. Chem., 2, 245, http://dx.doi.org/10.1071/EN05077doi:10.1071/EN05077, 2005.

O’Dowd, C. D., Jimenez, J. L., Bahreini, R., Flagan, R. C., Seinfeld, J. H., Hameri, K., Pirjola, L., Kulmala, M., Jennings, S. G., and Hoffmann, T.: Marine aerosol formation from biogenic iodine emissions, Nature, 417, 632-636, 2002.

Pedersén, M., Collén, J., Abrahamsson, K., and Ekdahl, A.: Production of halocarbons by seaweeds: an oxidative stress reaction?, Sci. Mar., 60, 257-263, 1996.

Peters, C., Pechtl, S., Stutz, J., Hebestreit, K., Hönninger, G., Heumann, K. G., Schwarz, A., Winterlik, J., and Platt, U.: Reactive and organic halogen species in three different European coastal environments, Atmos. Chem. Phys., 5, 3357-3375, http://dx.doi.org/10.5194/acp-5-3357-2005doi:10.5194/acp-53357-2005, 2005.

Platt, U. and von Glasow, R.: Halogens in the troposphere - an international task, Science and Implementation Plan, Geophys. Res. Abstr., 7, 07581, White Paper, available online at: www. uea.ac.uk/ fkd06bju/HitT/HitT_WhitePaper.pdf, last access: 20 July 2012, 2005.

Platt, U. and Hönninger, G.: The role of halogen species in the troposphere, Chemosphere, 52, 325-338, 2003.

Platt, U. and Perner, D.: Direct measurements of atmospheric $\mathrm{CH}_{2} \mathrm{O}, \mathrm{HNO}_{2}, \mathrm{O}_{3}, \mathrm{NO}_{2}, \mathrm{SO}_{2}$ by differential optical absorption in the near UV, J. Geophys. Res., 85, C12, 7453-7458, 1980.

Platt, U. and Stutz, J.: Differential Optical Absorption Spectroscopy - Principles and Applications, Springer-Verlag, Berlin Heidelberg, ISBN 978-3-540-21193-8, 2008.

Pundt, I., Pommereau, J.-P., Phillips, C., and Lateltin, E.: Upper limits of iodine oxide in the lower stratosphere, J. Atmos. Chem., 30, 173-185, 1998.

Read, K. A., Mahajan, A. S., Carpenter, L. J., Evans, M. J., Faria, B. V. E., Heard, D. E., Hopkins, J. R., Lee, J. D., Moller, S. J., Lewis, A. C., Mendes, L., McQuaid, J. B., Oetjen, H., Saiz-Lopez, A., Pilling, M. J., and Plane, J. M. C.: Extensive halogen-mediated ozone destruction over the tropical Atlantic Ocean, Nature, 453, 1232-1235, http://dx.doi.org/10.1038/ nature07035doi:10.1038/nature07035, 2008.

Richter, A., Wittrock, F., Eisinger, M., and Burrows, J. P.: GOME observations of tropospheric $\mathrm{BrO}$ in Northern Hemispheric spring and summer 1997, Geophys. Res. Lett., 25, 2683-2686, 1998.

Richter, A., Wittrock, F., Ladstätter-Weißenmayer, A., and Burrows, J. P.: GOME measurements of stratospheric and tropospheric BrO, Adv. Space Res., 29, 11, 1667-1672, 2002.
Rozanov, A., Rozanov, V.-V., Buchwitz, M., Kokhanovsky, A., and Burrows, J. P.: SCIATRAN 2.0. A new radiative transfer model for geophysical applications in the $175-2400 \mathrm{~nm}$ spectral region, Adv. Space Res., 36, 1015-1019, http://dx.doi.org/10.1016/j.asr. 2005.03.012doi:10.1016/j.asr.2005.03.012, 2005a.

Rozanov, A., Bovensmann, H., Bracher, A., Hrechanyy, S., Rozanov, V., Sinnhuber, M., Stroh, F., and Burrows, J. P.: $\mathrm{NO}_{2}$ and $\mathrm{BrO}$ vertical profile retrieval from SCIAMACHY limb measurements: sensitivity studies, Adv. Space Res., 36, 846-854, $2005 b$.

Rozanov, V. V., Buchwitz, M., Eichmann, K.-U., de Beek, R., and Burrows, J. P.: Sciatran - a new radiative transfer model for geophysical applications in the $240-2400 \mathrm{~nm}$ spectral region: the Pseudo-spherical version, Adv. Space Res., 29, 1831-1835, 2002.

Saiz-Lopez, A. and Boxe, C. S.: A mechanism for biologicallyinduced iodine emissions from sea-ice, Atmos. Chem. Phys. Discuss., 8, 2953-2976, http://dx.doi.org/10.5194/ acpd-8-2953-2008doi:10.5194/acpd-8-2953-2008, 2008.

Saiz-Lopez, A., Shillito, J. A., Coe, H., and Plane, J. M. C.: Measurements and modelling of $\mathrm{I}_{2}, \mathrm{IO}, \mathrm{OIO}, \mathrm{BrO}$ and $\mathrm{NO}_{3}$ in the mid-latitude marine boundary layer, Atmos. Chem. Phys., 6, 1513-1528, http://dx.doi.org/10.5194/ acp-6-1513-2006doi:10.5194/acp-6-1513-2006, 2006.

Saiz-Lopez, A., Mahajan, A. S., Salmon, R. A., Bauguitte, S. J.-B., Jones, A. E., Roscoe, H. K., and Plane, J. M. C.: Boundary layer halogens in coastal Antarctica, Science, 317, 348-351, http://dx. doi.org/10.1126/science.1141408doi:10.1126/science.1141408, 2007a.

Saiz-Lopez, A., Chance, K., Liu, X., Kurosu, T. P., and Sander, S. P.: First observations of iodine oxide from space, Geophys. Res. Lett., 34, L12812, http://dx.doi.org/10.1029/ 2007GL030111doi:10.1029/2007GL030111, 2007 b.

Saiz-Lopez, A., Plane, J. M. C., Mahajan, A. S., Anderson, P. S., Bauguitte, S. J.-B., Jones, A. E., Roscoe, H. K., Salmon, R. A., Bloss, W. J., Lee, J. D., and Heard, D. E.: On the vertical distribution of boundary layer halogens over coastal Antarctica: implications for $\mathrm{O}_{3}, \mathrm{HO}_{\mathrm{x}}, \mathrm{NO}_{\mathrm{x}}$ and the $\mathrm{Hg}$ lifetime, Atmos. Chem. Phys., 8, 887-900, http://dx.doi.org/10.5194/ acp-8-887-2008doi:10.5194/acp-8-887-2008, 2008.

Saiz-Lopez, A., Ordoñez, C., Gomez Martin, J. C., Lamarque, J.-F., and Kinnison, D. E.: Global modelling of upper troposphericlower stratospheric iodine: budget and implications for ozone, Geophysical Research Abstracts, Vol. 14, EGU2012-8580, EGU General Assembly, 2012.

Sander, R., Burrows, J., and Kaleschke, L.: Carbonate precipitation in brine - a potential trigger for tropospheric ozone depletion events, Atmos. Chem. Phys., 6, 4653-4658, http://dx.doi.org/10. 5194/acp-6-4653-2006doi:10.5194/acp-6-4653-2006, 2006.

Saunders, R. W., Kumar, R., Gomez-Martin, J. C., Mahajan, A. S., Murray, B. J., and Plane, J. M. C.: Studies of the formation and growth of aerosol from molecular iodine precursor, Z. Phys. Chem., 224, 1095-1117, doi:10.1524/zpch.2010.6143, 2010.

Schönhardt, A., Richter, A., Wittrock, F., Kirk, H., Oetjen, H., Roscoe, H. K., and Burrows, J. P.: Observations of iodine monoxide columns from satellite, Atmos. Chem. Phys., 8, 637653, http://dx.doi.org/10.5194/acp-8-637-2008doi:10.5194/acp8-637-2008, 2008. 
Schönhardt, A., Richter, A., and Burrows, J. P.: Iodine Monoxide and the relations to sea ice and biological activity, Proc. of ESA, SOLAS \& EGU Joint Conference "Earth Observation for OceanAtmosphere Interactions Science" Frascati, Italy, 29 November 2 December 2011, ESA SP-703, March 2012.

Schroeder, W. H., Anlauf, K. G., Barrie, L. A., Lu, J. Y., Steffen, A., Schneeberger, D. R., and Berg, T.: Arctic springtime depletion of mercury, Nature, 394, 331-332, 1998.

Shaw, G. E.: Antarctic aerosols: A review, Rev. Geophys., 26, 89112, 1988.

Simpson, W. R., Carlson, D., Hönninger, G., Douglas, T. A., Sturm, M., Perovich, D., and Platt, U.: First-year sea-ice contact predicts bromine monoxide $(\mathrm{BrO})$ levels at Barrow, Alaska better than potential frost flower contact, Atmos. Chem. Phys., 7, 621627, http://dx.doi.org/10.5194/acp-7-621-2007doi:10.5194/acp7-621-2007, 2007a.

Simpson, W. R., von Glasow, R., Riedel, K., Anderson, P., Ariya, P., Bottenheim, J., Burrows, J., Carpenter, L. J., Frieß, U., Goodsite, M. E., Heard, D., Hutterli, M., Jacobi, H.-W., Kaleschke, L., Neff, B., Plane, J., Platt, U., Richter, A., Roscoe, H., Sander, R., Shepson, P., Sodeau, J., Steffen, A., Wagner, T., and Wolff, E.: Halogens and their role in polar boundary-layer ozone depletion, Atmos. Chem. Phys., 7, 4375-4418, http://dx.doi.org/10.5194/ acp-7-4375-2007doi:10.5194/acp-7-4375-2007, $2007 \mathrm{~b}$.

Solomon, S., Sanders, R. W., Carroll, M. A., and Schmeltekopf, A. L.: Visible and near-ultraviolet spectroscopy at McMurdo Station, Antarctica. 5. Observations of the diurnal variations of $\mathrm{BrO}$ and OClO, J. Geophys. Res., 94, D9, 11393-11403, 1989.

Solomon, S., Garcia, R. R., and Ravishankara, A. R.: On the role of iodine in ozone depletion, J. Geophys. Res., 99, 20491-20499, 1994.

Spreen, G., Kaleschke, L., and Heygster, G.: Sea ice remote sensing using AMSR-E $89 \mathrm{GHz}$ channels, J. Geophys. Res., 113, C02S03, http://dx.doi.org/10.1029/ 2005JC00338doi:10.1029/2005JC00338, 2008.

Steffen, A., Douglas, T., Amyot, M., Ariya, P., Aspmo, K., Berg, T., Bottenheim, J., Brooks, S., Cobbett, F., Dastoor, A., Dommergue, A., Ebinghaus, R., Ferrari, C., Gardfeldt, K., Goodsite, M. E., Lean, D., Poulain, A. J., Scherz, C., Skov, H., Sommar, J., and Temme, C.: A synthesis of atmospheric mercury depletion event chemistry in the atmosphere and snow, Atmos. Chem. Phys., 8, 1445-1482, http://dx.doi.org/10.5194/ acp-8-1445-2008doi:10.5194/acp-8-1445-2008, 2008.

Theys, N., Van Roozendael, M., Hendrick, F., Yang, X., De Smedt, I., Richter, A., Begoin, M., Errera, Q., Johnston, P. V., Kreher, K., and De Mazière, M.: Global observations of tropospheric BrO columns using GOME-2 satellite data, Atmos. Chem. Phys., 11, 1791-1811, http://dx.doi.org/10.5194/ acp-11-1791-2011doi:10.5194/acp-11-1791-2011, 2011.
Thomas, D. N. and Diekmann, G. S. (Eds.): Sea Ice: An introduction to its physics, chemistry, biology and geology, Blackwell Publishing Company, Oxford, UK, 2003.

Tokarczyk, R. and Moore, R. M.: Production of volatile organohalogens by phytoplankton cultures, Geophys. Res. Lett., 21, 4, 285288, 1994.

Vogt, R., Sander, R., von Glasow, R., and Crutzen, P. J.: Iodine chemistry and its role in halogen activation and ozone loss in the marine boundary layer: a model study., J. Atmos. Chem., 32, 375-395, 1999.

Volkamer, R., Coburn, S., Dix, B., Sinreich, R., Lechner, M., Atlas, E., Guenther, A., Duhl, T., Sommariva, R., von Glasow, R., Myriokefalitakis, S., and Kanakidou, M.: Controls from a widespread surface ocean organic micro layer on atmospheric oxidative capacity, Geophysical Research Abstracts, 14, EGU2012-6761-1, EGU General Assembly, 2012.

Vountas, M., Rozanov, V. V., and Burrows, J. P.: Ring effect: impact of rotational Raman scattering on radiative transfer in Earth's atmosphere, J. Quant. Spectrosc. Ra., 60, 943-961, 1998.

Wada, R., Beames, J. M., and Orr-Ewing, A. J.: Measurement of IO radical concentrations in the marine boundary layer using a cavity ring-down spectrometer, J. Atmos. Chem., 58, 69-87, http: //dx.doi.org/10.1007/s10874-007-9080-zdoi:10.1007/s10874007-9080-z, 2007.

Wagner, T. and Platt, U.: Satellite mapping of enhanced BrO concentration in the troposphere, Nature, 395, 486-490, 1998.

Wagner, T., Leue, C., Wenig, M., Pfeilsticker, K., and Platt, U.: Spatial and temporal distribution of enhanced boundary layer $\mathrm{BrO}$ concentrations measured by the GOME instrument aboard ERS2, J. Geophys. Res., 106, D20, 24225-24235, 2001.

Whalley, L. K., Furneaux, K. L., Gravestock, T., Atkinson, H. M., Bale, C. S. E., Ingham, T., Bloss, W. J., and Heard, D. E.: Detection of iodine monoxide radicals in the marine boundary layer using laser induced fluorescence spectroscopy, J. Atmos. Chem., 58, 19-39, http://dx.doi.org/10.1007/ s10874-007-9075-9doi:10.1007/s10874-007-9075-9, 2007.

Wittrock, F., Eisinger, M., Ladstätter-Weißenmayer, A., Richter, A., and Burrows, J. P.: Ground-based UV/VIS measurements of $\mathrm{O}_{3}$, $\mathrm{NO}_{2}, \mathrm{BrO}$, and $\mathrm{OClO}$ over $\mathrm{Ny}$-Ålesund $\left(79^{\circ} \mathrm{N}, 12^{\circ} \mathrm{E}\right)$, in: Proc. XVIII Quadrennial Ozone Symposium, L'Aquila, Italy, September 1996, 2, 623-626, 1996.

Wittrock, F., Müller, R., Richter, A., Bovensmann, H., and Burrows, J. P.: Measurements of iodine monoxide (IO) above Spitsbergen, Geophys. Res. Lett., 27, 1471-1474, 2000. 